\title{
Stenostephanus (Acanthaceae) in Peru
}

\author{
John R. I. Wood ${ }^{1,2}$ (D)
}

Summary. An account of the hill forest genus Stenostephanus Nees in Peru is presented. The salient characteristics and distribution of the genus are outlined to provide a wider context for the Peruvian species. Five new species, S. antiquorum J.R.I.Wood, S. atrocalyx J.R.I.Wood, S. cuscoensis J.R.I.Wood, S. densiflorus J.R.I.Wood and S. wasshausenii J.R.I.Wood are described as well as two varieties, var. angustissimus J.R.I.Wood and var. hirtiflorus J.R.I.Wood of S. longistamineus (Ruiz \& Pav.) V.M.Baum. A key to all species occurring in Peru is provided together with diagnostic summaries of their salient characteristics and maps of their distribution. The new taxa are illustrated with line drawings and their conservation status is assessed.

Key Words. Bolivia, Brazil, Ecuador, new species, taxonomy.

Stenostephanus Nees is an entirely neotropical genus of around 80 species. It is distributed along mountains from south central Mexico through Central America and then along the Andes from Venezuela south to the Santa Cruz region in central Bolivia. A single species, S. lobeliiformis Nees occurs in the Atlantic Forest of southeastern Brazil. The greatest diversity is found in Colombia from where 29 species are known (Wood 2009, 2016). There are accounts of the genus in Bolivia (Wasshausen 1999a; Wasshausen \& Wood 2004), in Ecuador (Wasshausen 2013) and in Colombia (Wood 1988, 2009) but no account of the genus has ever been published for Peru. This paper aims to rectify this omission.

Stenostephanus species are herbs or weak subshrubs with decumbent, ascending or erect stems up to about $3 \mathrm{~m}$ in height. Cystoliths are present, particularly on the leaves but sometimes also on other vegetative parts. Stems are often swollen at the nodes. Leaves are entire to undulate, usually equal to slightly unequal in each pair but strongly anisophyllous plants are apparently unknown. The inflorescence is commonly a terminal thyrse but small cymes or thyrses may arise in the upper leaf axils. Prominent bracts may be present at the base of the thyrse but diminish in size upwards at each branching point. The whole inflorescence may be glabrous or glandular-hairy, the glandular hairs often developing as the inflorescence matures. The calyx is divided to near the base into five equal, usually narrowly lanceolate lobes, these somewhat accrescent in fruit. The corolla may be tubular, \pm suburceolate with four short lobes, or more or less 2-lipped with a simple upper lip and a 3-lobed, often spreading lower lip. In colour, the corolla may be blue, yellow, red, purple, pink or bicoloured. The androecium consists of two, usually exserted stamens, inserted above the basal part of the corolla tube, each stamen with a monothecous anther. The pollen is of a characteristic shape resembling an aeroplane wheel. The gynoecium consists of a narrowly oblong ovary and single style with a very small stigma. The fruit is an oblong 4-seeded, stipitate capsule, the seeds discoid or lenticular, often tuberculate.

The corolla of Stenostephanus is highly variable and variation in its form was the main justification for several segregate genera previously recognised but now subsumed into Stenostephanus. Four corolla types can be discerned in Peruvian species. In $S$. sprucei (Lindau) Wassh. \& J.R.I.Wood, previously placed in Cylindrosolenium Lindau, the three lower corolla lobes are relatively long, linear-filiform, flexuose and resembling the upper lip so the corolla appears to be deeply 4-lobed. S. davidsonii Wassh. and S. macrolobus (Lindau) J.R.I.Wood have strongly 2-lipped corollas but with the lower lip shallowly lobed. Previously they would have been placed in Habracanthus Nees. It is probable that the species treated below as Stenostephanus sp. A also belongs to this group but in the absence of corollas it is impossible to be sure. Weakly 2-lipped are the corollas of S. wallnoeferi Wassh. and S. longistamineus (Ruiz \& Pav.) V.M.Baum. These have a bent or falcate corolla tube which is narrowly obovoid in bud. S. longistamineus and its allies also have a rather distinct calyx with short, essentially lanceolate lobes, broad at the base but abruptly narrowed to a filiform apex. The remaining species from Peru

Accepted for publication 3 September 2019. Published online 20 December 2019

1 Department of Plant Sciences, University of Oxford, South Parks Road, Oxford, OX1 3RB, U.K.. e-mail: jriwood@hotmail.com

2 Royal Botanic Gardens, Kew, Richmond, Surrey, TW9 3AB, U.K.. 
belong to a group with a tubular corolla with very short lobes, which were or would have been included in the genus Hansteinia Oerst.

Stenostephanus is a characteristic cloud forest species with a few species occurring in lower altitude rain forest but, apart from S. longistamineus, always on or near mountainous regions. Most species are very local endemics, often known from a single locality or with a very restricted range. Many appear to flower irregularly, perhaps in response to particular climatic conditions. One Mexican species is confirmed to be plietesial (Daniel 2006) but it is quite probable that other species are also plietesial. Species with a tubular red flower (the majority of species in Peru) are presumably hummingbird-pollinated but very little reliable information is known about the pollination of these plants. Species with strongly 2-lipped corollas tend to occur at higher altitudes $(1500-2500 \mathrm{~m})$ than those with a subcylindical corolla.

In morphology, pollen and ecology, Stenostephanus is very similar to the African genus, Brachystephanus Nees and it is difficult to see how the two genera can be consistently distinguished. Champluvier \& Darbyshire (2009) compared the two genera in some detail but decided that no attempt to unite them should be made before further molecular studies were made. Stenostephanus is the older name so there is no threat to the nomenclatural stability of the neotropical species.
This paper is essentially based on the study of dried specimens from four herbaria: the Field Museum (F), the Royal Botanic Gardens at Kew (K), Missouri Botanical Garden (MO) and the Smithsonian Institution in Washington (US). Reference has been made to relevant publications, which are cited in the list of references, and observations have been informed by the author's knowledge of the genus in the field, albeit outside Peru. Full descriptions are provided of the five new species and of Stephanus longistamineus, the latter because of the description of two new infraspecific taxa. Diagnostic notes are provided for other recognised species. Maps have been constructed based on the coordinates provided on recent collection labels augmented by inferred coordinates from locations provided by earlier collectors. Species are arranged alphabetically in the following account.

This paper recognises 12 species from Peru, of which are seven are endemic. Five are described as new but there are probably other undescribed species as some specimens cannot be readily assigned to species. This number is similar to that of Ecuador (eight species) and Bolivia (currently 11, but two more in preparation for publication), but much less than that of Colombia (29).

Species occurring in Peru can be distinguished by the following key, but this will only work well with plants that have buds and open corollas.

\section{Key to species of Stenostephanus occurring in Peru}

1. Corolla with linear-filiform, flexuose upper lip, similar to the three lobes of the lower lip; flowers sessile; calyx 2 - $3 \mathrm{~mm}$ long; inflorescence of axillary spikes with pale lilac flowers arranged in verticillasters . . . S. sprucei Corolla terminating in four short teeth or lobes or, if distinctly 2-lipped, the lower lip only shallowly lobed; flowers not completely sessile; calyx at least $3 \mathrm{~mm}$ long; inflorescence not as above . . . . . . . . . 2

2. Corolla yellow with reddish-orange bands, pubescent, strongly ventricose, c. $1 \mathrm{~cm}$ long; inflorescence densely glandular-pilose, appearing to be formed of dense branched spikes . . . . . . . . . . . S. lasiostachyus Corolla pink or reddish, but if yellow or cream $1.5-2 \mathrm{~cm}$ long, glabrous or pubescent, not strongly ventricose; inflorescence lax or spicate, lacking gland-tipped trichomes or, if present, very few. . . . . . . . . 3

3. Inflorescence relatively lax, diffuse or forming an open thyrse; corolla small, $1-1.8 \mathrm{~cm}$ long; sepals linear-

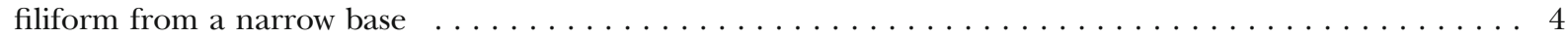
Inflorescence spicate, racemose or lax and paniculate; corolla $>1.7 \mathrm{~cm}$ long; sepals varied but if linear-filiform,

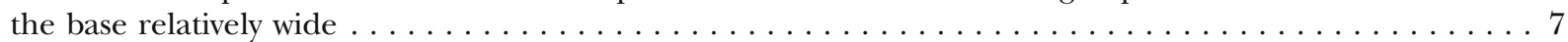

4. Corolla red; inflorescence diffuse, entirely glabrous . . . . . . . . . . . . . . . . S. jamesonii Corolla white, cream or pink; inflorescence a subracemose to subpyramidal thyrse, the rhachis, peduncles,

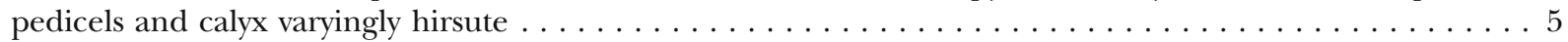

5. Corolla glabrous or nearly so, white or cream; ovary and capsule glabrous $\ldots \ldots \ldots$ Corolla hirsute on the exterior, pink (or white?); ovary and capsule pubescent . . . . . . . S. macrolobus

6. Inflorescence a narrow subracemose thyrse; stems densely villous . . . . . . . . . . . . . . S. sp. A Inflorescence an open thyrse, not clearly racemose in form; stems appressed or crisped pubescent ............................... . davidsonii

7. Inflorescence a dense thyrse with imbricate flowers; bracts at branching points of thyrse obovate-subrhomboid to ovate, conspicuous, persistent; corolla $3-4 \mathrm{~cm}$ long, pubescent apically . . . . . . . . . . S. densiflorus Inflorescence of various forms but the flowers never densely imbricate; bracts and bracteoles linear, inconspicuous or apparently absent; corolla, if $>3 \mathrm{~cm}$ long, glabrous $\ldots \ldots \ldots$ 


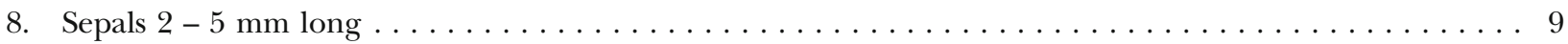

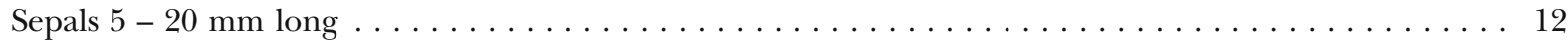

9. Inflorescence a narrow, elongate spicate raceme c. $20 \mathrm{~cm}$ in length, the peduncles and pedicels almost

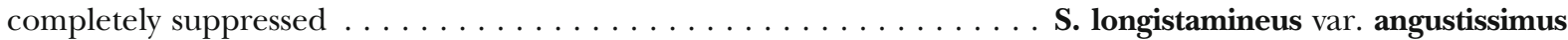
Inflorescence lax, usually $<12 \mathrm{~cm}$ long, the pedicels and peduncles well-developed and conspicuous . . . 10

10. Calyx conspicuously pubescent; corolla pubescent at least at the apex, the tube $1.5-2 \mathrm{~cm}$ long; inflorescence


Calyx glabrous or pubescent; corolla glabrous, tube $2-3.8 \mathrm{~cm}$ long; inflorescence usually much longer than



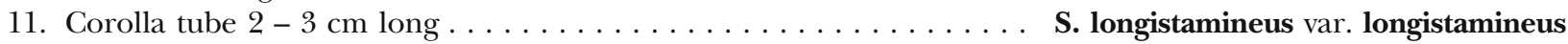



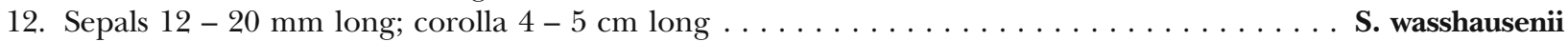

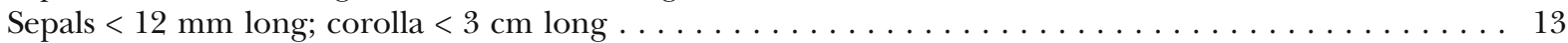

13. Sepals narrowly oblong, obtuse, dark in colour; corolla with glandular hairs at apex . . . . . . . S. atrocalyx Sepals filiform, attenuate at apex, pale green; corolla glabrous or pubescent but not comose with glandular

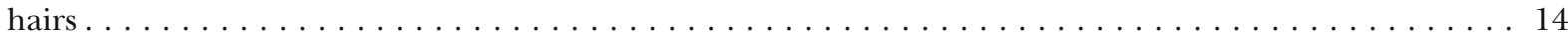

14. Inflorescence an elongate raceme; peduncles c. $3 \mathrm{~mm}$ long; corolla uniformly pubescent on the exterior...............15 Inflorescence diffuse, shortly racemose or not clearly structured; peduncles $5-15 \mathrm{~mm}$ long; corolla

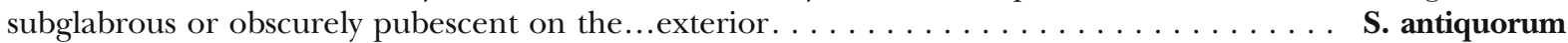

15. Corolla $1.9-2 \mathrm{~cm}$ long, creamy yellow; rhachis and sepals villous . . . . . . . . . . . . S. sp. B

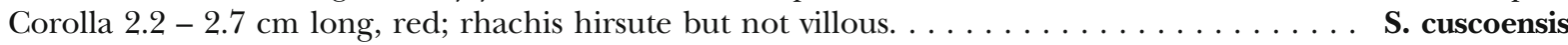

Stenostephanus antiquorum J.R.I.Wood, sp. nov. Type: Peru, Cusco, Urubamba, Sanctuario historico de Macchupiccu y el Camino Inca, $13^{\circ} 09^{\prime} \mathrm{S} 72^{\circ} 31^{\prime} \mathrm{W}$, 2300 - 4150 m, 16 March 1988, P. Nuñez Eं F. Luna 8865 (holotype F2028096, isotypes MO, US).

http:/ /www.ipni.org/urn:lsid:ipni.org:names:60479358-2

Subshrub/woody herb to $1.5 \mathrm{~m}$; stems somewhat sulcate, pubescent in the depressions, glabrescent when old and woody parts glabrous. Leaves petiolate; petioles 0.5 - $4 \mathrm{~cm}$, crisped pubescent; lamina oblong-elliptic to obovate, shortly acuminate, base attenuate and somewhat decurrent onto the petiole; both surfaces very thinly to rather densely pubescent, with abundant short cystoliths, abaxially paler and sometimes the veins with denser pubescence; veins $10-11$ pairs. Inflorescence of very lax, few-flowered axillary racemes, arising from the upper leaf axils, often reduced to a few flowers; rhachis $7-16 \mathrm{~cm}$, densely hirsute; bracts at base of raceme resembling small leaves; at branching points resembling bracteoles; bracteoles linear, minute, c. $1.5 \mathrm{~mm}$ long, crisped pubescent; peduncles 5 - $15 \mathrm{~mm}$, simple or forked, crisped pubescent; secondary peduncles shorter; pedicels 1 $2 \mathrm{~mm}$; calyx with rounded base c. $1 \mathrm{~mm}$ long, 5-lobed, the lobes linear-attenuate $6-9$ (- 13) $\mathrm{mm}$ long, somewhat accrescent in fruit, very sparsely and shortly hirsute; corolla $2-3.5 \mathrm{~cm}$, red, subcylindrical, the basal part narrow up to $9 \mathrm{~mm}$ long, $1-2 \mathrm{~mm}$ wide, then slightly, but abruptly widened to $3-4 \mathrm{~mm}$, the tube nearly glabrous but the apical portion with a few scattered hairs, obscurely 2-lipped, the upper lip lanceolate, c. $5 \mathrm{~mm}$ long, the lower lip shorter, with short oblong lobes c. $2 \mathrm{~mm}$ long; filaments glabrous, anthers exserted to $12 \mathrm{~mm}, 4 \mathrm{~mm}$ long; style $3.1 \mathrm{~mm}$ long, glabrous, persistent; stigma globose, ovary hirsute. Capsule $15 \times 2.5 \mathrm{~mm}$, clavate, hirsute; 4-seeded; seeds lenticular, $2.25 \times 1.5 \mathrm{~mm}$, reticulate. Fig. $1 \mathrm{~A}-\mathrm{M}$.

RECOGNITION. Resembles Stenostephanus crenulatus (Britton ex Rusby) Wassh. in the shape and colour of the corolla and appearance of the inflorescence but differs in the hirsute (not glabrous) ovary and capsule, shortly pubescent (not glabrous) corolla and especially in the shape of the calyx whose lobes are linearfiliform $6-11 \mathrm{~mm}$ in length, not deltoid, $2-3 \mathrm{~mm}$ long.

HABITAT \& DISTRIBUTION. Humid montane forest usually between $2100-2800 \mathrm{~m}$ in the Peruvian Andes. Endemic to the area around Macchu Pichu in the Cusco region of southern Peru. Map 1.

SPECIMENS EXAMINED. PERU. Cusco: Estación de Macchu Pichu, 2300 m, 15 March 1965, A. Aldave 4932 (US); La Convención, Santa Ana. Poromate, 12 $55^{\circ} \mathrm{S} 72^{\circ} 47^{\prime} \mathrm{W}, 2118 \mathrm{~m}$, G. Calatayud et al. 1443 (US); Santa Ana, Madre Selva. 2300 - 3200 m, 20 March 2003, L. Valenzuela et al. 3041 (MO, OXF); La Convención, Huayopata, Incatambo, Quebrada Curcur, Cuenca del Lucumayo, $13^{\circ} 02^{\prime} \mathrm{S} 72^{\circ} 15^{\prime} \mathrm{W}$, 2326 m, 17 Nov. 2004, L. Valenzuela et al. 4353 (MO, US); Santa Teresa, Yanatile, $13^{\circ} 05^{\prime} \mathrm{S} 72^{\circ} 23^{\prime} \mathrm{W}, 2950 \mathrm{~m}$, 16 April 2005, L. Valenzuela et al. 5371 (MO, US); Santa Teresa, Yanatile, $13^{\circ} 05^{\prime} \mathrm{S} 72^{\circ} 24^{\prime} \mathrm{W}, 1800 \mathrm{~m}, 18$ April 2005, L. Valenzuela et al. 5513 (MO); La Convención, Maranura, Mesa Pelada, 12³3'S 72²2'W, 2536 m, 21 


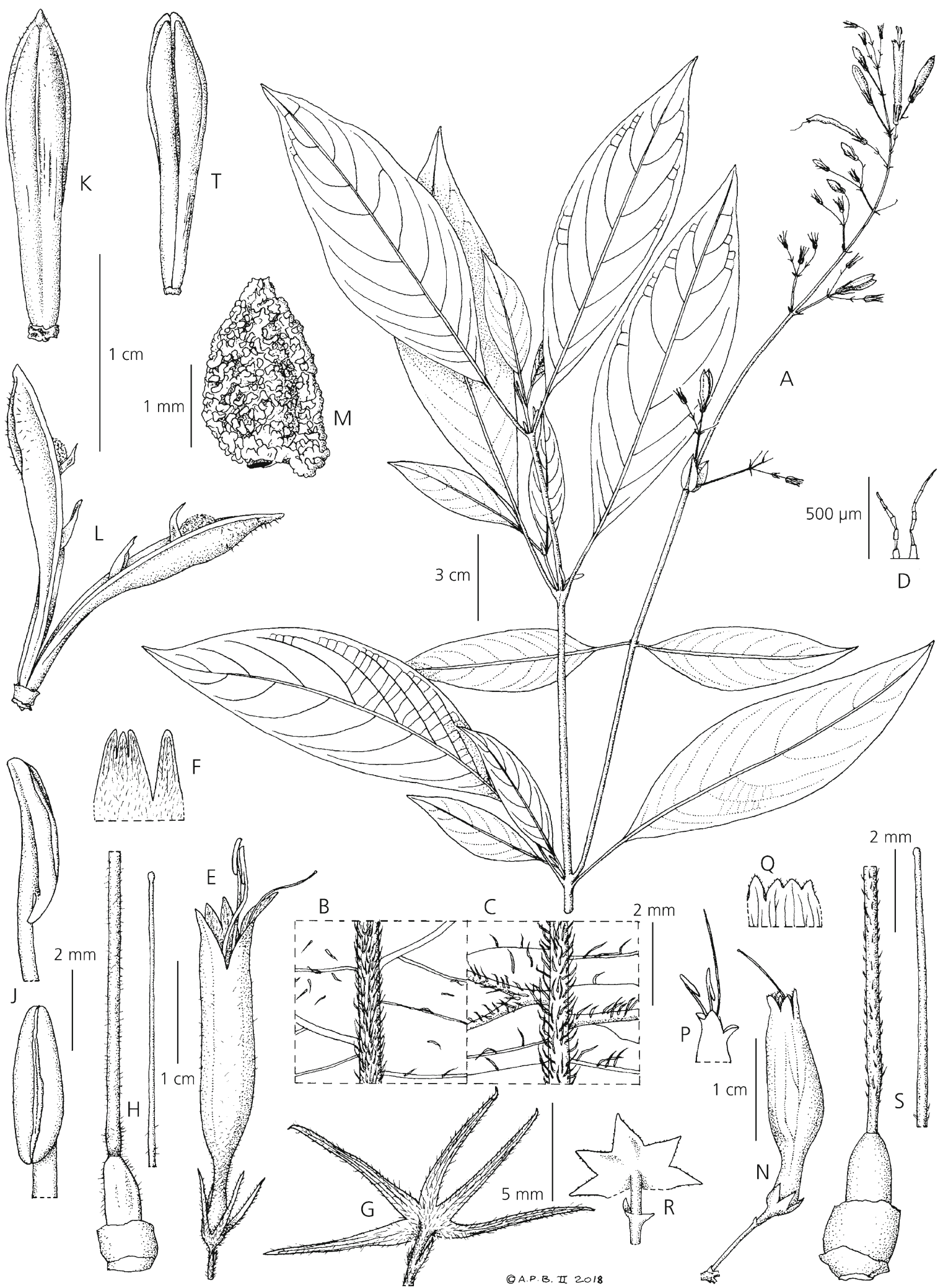

Fig. 1. A - M Stenostephanus antiquorum: A habit; B adaxial leaf surface; C abaxial leaf surface; D detail of hair on abaxial leaf surface; E flower; F corolla lobes (scale bar as for ovary); G calyx opened out; $\mathrm{H}$ ovary, style and stigma (scale bar to left refers to ovary but that on the right to the upper part of style); J anthers; $\mathrm{K}$ capsule; $\mathrm{L}$ capsule opening to show seeds; $\mathrm{M}$ seed. $\mathrm{N}-\mathrm{T}$ Stenostephanus crenulatus N flower; P apex of corolla with exserted stamens; Q corolla lobes (scale bar as for S); R calyx lobes; S ovary and style; T capsule. A - D, K - M from Huamatupa et al. 3116; E, G - H from Peyton et al. 1230, F, J from Nuñez et al. 8865; N - Q from Wood et al. 14551; P from Zenteno 559; T from Wood et al. 18146. DRAWN BY ANDREW BROWN. 


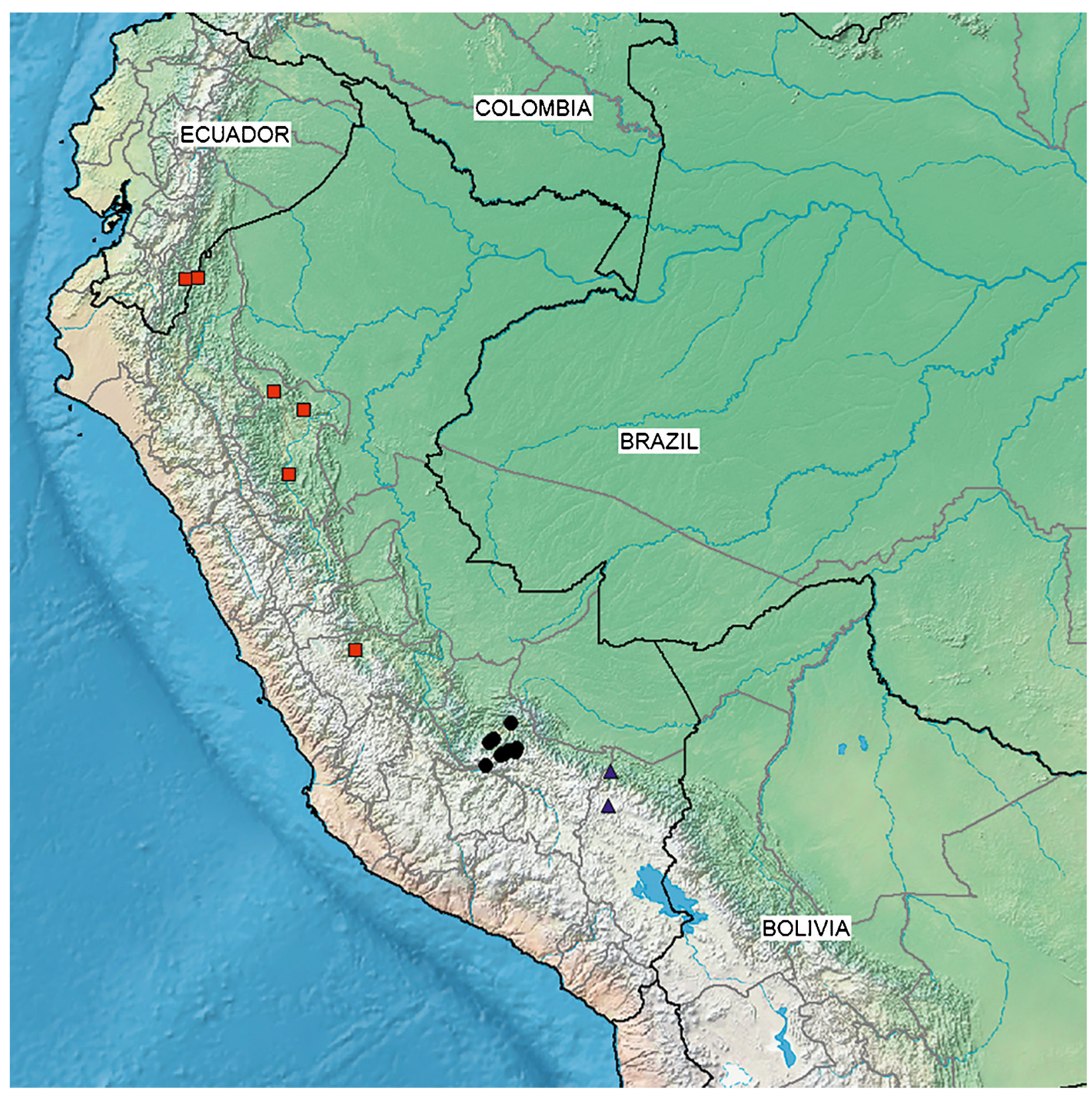

Map 1. Map of Peru and neighbouring countries showing distribution of Stenostephanus antiquorum (black circles), S. sprucei (red squares) and S. wasshausenii (blue triangles).

April 2005, L. Valenzuela et al. 5632 (US); Santa Teresa, on a hill called Mandornilloc, $0.5 \mathrm{~km}$ W of La Playa, 2475 m, 9 Sept. 1982, B. E S. T. Peyton 1230 (MO, US); Urubamba, Machu Pichu, Alcamayo, $2800 \mathrm{~m}, 16$ May 2003, I. Huamatupa et al. 3116 (US); Urubamba, Sanctuario Historico de Macchupiccu y el Camino Inca, $13^{\circ} 09^{\prime} \mathrm{S} 72^{\circ} 31^{\prime} \mathrm{W}, 2300$ - $4150 \mathrm{~m}, 16$ March 1988, P. Nunez Eु F. Luna. 8865 (F, MO, US); Urubamba, $0.5 \mathrm{~km}$ above junction of Sayacmarca and Aobamba Rs, 2280 m, 10 Oct. 1982, B. Eं S. T. Peyton et al. 1451 (US); $0.5 \mathrm{~km}$ above junction of Sayacmarca and Aobamba Rios, 2160 m, 14 Oct. 1982, B. E S. T.
Peyton 1502 (US); Macchu Pichu, Pampacahua, 2485 m, 22 Jan. 2005, L. Valenzuela et al. 4653 (US).

CONSERVATION STATUS. With an area of occupancy of $48,000 \mathrm{~km}^{2}$ and an extent of occurrence of 3178.183 $\mathrm{km}^{2}$, based on Geocat, this species should be provisionally classified as Endangered (EN) following IUCN guidelines. Some sites lie within the Area de Conservación Regional Choquequirao but Andean forest is very vulnerable to clearance and it is not clear how secure the conservation area is.

EPONYMY. This species is named "antiquorum" because it is chiefly found around Macchu Pichu, 
the most famous remains of ancient civilisation in Peru.

Stenostephanus atrocalyx J.R.I.Wood, sp. nov. Type: Peru, Cusco, Quispicanchis, along trail $25 \mathrm{~km}$ SW of Quincemil, 1340 m, 8 Oct. 1976, D. C. Wasshausen E F. Encarnación 744 (holotype US2957324, isotype K).

http:/ /www.ipni.org/urn:lsid:ipni.org:names:60479359-2

Shrub $1-2.5$ high; stems glabrous, weakly quadrangular. Leaves slightly unequal in each pair, petiolate; lamina narrowly to broadly oblong-elliptic, $4-23 \times 1.2-8.5 \mathrm{~cm}$, acuminate, base attenuate and briefly decurrent, margin obscurely crenate, glabrous, adaxially with cystoliths, abaxially paler, veins c. 10 pairs, reticulate, with prominent cystoliths; petioles $0.3-2 \mathrm{~cm}$. Inflorescence a solitary terminal narrowly pyramidal, lax thyrse, c. $7-24 \times 4-$ $5 \mathrm{~cm}$ (occasionally also with two axillary spikes arising from the axils of the basal bracts), rhachis glabrous, the dichasia in opposite pairs, the lowermost up to $3 \mathrm{~cm}$ apart, bracts at base of thyrse resembling reduced sessile leaves, peduncles $11-21 \mathrm{~mm}$, primary bracteoles linearlanceolate $3 \mathrm{~mm}$, secondary peduncles $4-8 \mathrm{~mm}$, secondary bracteoles $1.5-2 \mathrm{~mm}$, filiform; pedicels 2 $5 \mathrm{~mm}$; calyx dark green to purplish, drying blackish, prominently parallel-veined, deeply 5-lobed to c. $1 \mathrm{~mm}$ above base, lobes linear-oblong, abruptly narrowed to a tiny point or mucro, the tips often spreading at anthesis, c. $6 \times 0.5 \mathrm{~mm}$ but accrescent in fruit to $9-10 \times 1 \mathrm{~mm}$ and becoming slightly oblanceolate, glabrous; corolla purplish-red or crimson, straight, glabrous, except for a few large-celled, spreading hairs at the apex, $1.7-2 \mathrm{~cm}$ long, tube constricted just above base, narrowly cylindrical for c. $4 \mathrm{~mm}$ then abruptly ventricose to $5 \mathrm{~mm}$, becoming narrower towards the apex, obscurely 2lipped, upper lip 3-4 mm, entire, lower lip slightly shorter, 3-toothed, the teeth c. $1.5 \mathrm{~mm}$; stamens exserted $1 \mathrm{~cm}$, filaments glabrous, anthers $3 \mathrm{~mm}$; style exserted, glabrous, stigma ellipsoid. Capsule $13-14 \times 3 \mathrm{~mm}$, clavate, glabrous, 4-seeded; seeds $2 \times 1.5 \mathrm{~mm}$, pale cream, reticulate, minutely puberulent. Fig. 2.

RECOGNITION. Distinguished by the inflorescence of lax thyrses, glabrous corolla and especially by the dark green (drying blackish) calyx with broad, linear-oblong lobes, abruptly narrowed at the apex and terminating in a fine mucro. No obvious close relatives have been noted apart from Stenostephanus wasshausenii described later in this paper, which has much larger floral dimensions (Fig. 8). S. atrocalyx has been compared in collector's notes with S. crenulatus but the calyx is much larger and different in shape (Figs 1R and 2G).

HABITAT \& DISTRIBUTION. Moist primary and secondary hill forest, often near streams, mostly between 1000 and $1500 \mathrm{~m}$. Endemic to the Andes in Peru occurring in two slightly disjunct areas, one in southern Peru and the other in the central region. Map 2.

SPECIMENS EXAMINED. PERU. Cusco: Río Arasa, NE of Cusco, 1200 m, Jan. 1943, C. Sandeman 3680 (K); Paucartambo, Callanga, Río Callanga, 1500 m, 26 Feb. 1953, Woytkowski 463 (K, USM); ibid., between Pilcopata and Pillahuata, $1020 \mathrm{~m}, 28$ June 1975, D. C. Wasshausen EF F. Encarnación 593 (K, US); ibid., Cosnipata valley, Río Tono, on ridge $\mathrm{N}$ of Patria, $13^{\circ} 07^{\prime} \mathrm{S} 71^{\circ} 12^{\prime} \mathrm{W}, 750-850 \mathrm{~m}, 27$ Nov. 1985, T. Wachter 85 (F); ibid., Kosnipata, Pongo de Koñec, $12^{\circ} 53^{\prime} 53^{\prime \prime S}$ $72^{\circ} 22^{\prime} 25^{\prime \prime W}, 800$ m, 28 Dec. 2005, I. Eं A. Huamantupa 7320 (MO, OXF); Quispicanchis, along trail $25 \mathrm{~km} \mathrm{SW}$ of Quincemil, 1340 m, 8 Oct. 1976, D. C. Wasshausen Ẽ F. Encarnación 744 (K, US); ibid., Camanti, Quincemil, $13^{\circ} 13^{\prime} 28^{\prime \prime S} 70^{\circ} 45^{\prime} 36^{\prime \prime W}, 622 \mathrm{~m}, 21$ Jan. 2007, L. Valenzuela et al. 8434 (MO, OXF); ibid., $13^{\circ} 12^{\prime} 55^{\prime \prime S} 70^{\circ} 46^{\prime} 04^{\prime \prime W}, 880 \mathrm{~m}, 16$ Dec. 2007, L. Valenzuela et al. 10624 (MO, OXF). Junín: Chanchamayo; Tulumayo valley, $5-10 \mathrm{~km} \mathrm{~S}$ of San Ramon, trail above La Esperanza to Rincón, $11^{\circ} 12^{\prime} \mathrm{S}$ $75^{\circ} 15^{\prime} \mathrm{W}, 1000$ - 1500 m, 5 Sept. 1982, R. B. Foster 8532 (US); Pichis trail, between San Nicholas and Azupizu, 650 - 900 m, 6 July 1929, E. P. Killip E A. C. Smith 26090 (US). Pasco: Oxapampa, Palcazu Valley, Río Pichinaz, $10^{\circ} 22^{\prime} \mathrm{S} 75^{\circ} 08^{\prime} \mathrm{W}, 600-800 \mathrm{~m}, 26$ Oct. 1982, R. B. Foster E̋ D. Smith 9436 (US); ibid., Palcazu, Río Alto Iscozacin, Ozuz to Río Pescado, $10^{\circ} 19^{\prime} \mathrm{S} 75^{\circ} 16^{\prime} \mathrm{W}$, $400-500$ m, 12 May 1985, R. B. Foster Eं B. D’Achille 10093 (F); ibid., Palcazu, Bosque de Protección San Matías-San Carlos, $10^{\circ} 45^{\prime} \mathrm{S} 74^{\circ} 55^{\prime} \mathrm{W}, 1350$ - 1420 m, 3 July 2003, A. Monteagudo E⿱ $G$. Ortiz 5703 (US); ibid., J. Perea $\mathcal{E}^{\circ}$ C. Mateo 127 (US); ibid., Palcazu, San Pedro de Pichanaz - Mirador Pichis, $10^{\circ} 30^{\prime} 15^{\prime \prime S} 75^{\circ} 04^{\prime} 01^{\prime \prime W}$, $700-1200$ m, 10 June 2004, R. Rojas et al. 2835 (US). Puno: Carabaya, 900 m, 12 June 1982, San Gaban D. C. Wasshausen Eे A. Salas 1244 (K). Madre de Dios: Manu, Atalaya, Hac. Amazonia, $2-3 \mathrm{~km} \mathrm{~W}$ of village across Río Alto Madre, $12^{\circ} 55^{\prime} \mathrm{S} 71^{\circ} 12^{\prime} \mathrm{W}, 500-600 \mathrm{~m}$, 12 Dec. 1983, R. Foster E T. Wachter 7398 (F).

CONSERVATION STATUS. With an area of occupancy of $60,000 \mathrm{~km}^{2}$ and an extent of occurrence of 43768.144 $\mathrm{km}^{2}$, based on Geocat, this species should be provisionally classified as Endangered (EN) in its area of occupancy but only Near Threatened (NT) in its extent of occurrence according to IUCN guidelines. As the habitat is vulnerable to forest clearance and the populations are disjunct, all apparently lying outside protected areas, a provisional classification of Endangered (EN) would seem appropriate until populations and their habitat can be properly assessed.

EPONYMY. This species is named "atrocalyx" because of the dark colour of the sepals, which appear black in dried specimens.

NOTE. The leaves of this species are quite variable in shape, from oblong to elliptic. Collectors have noted that it is visited by hummingbirds, something that it is 


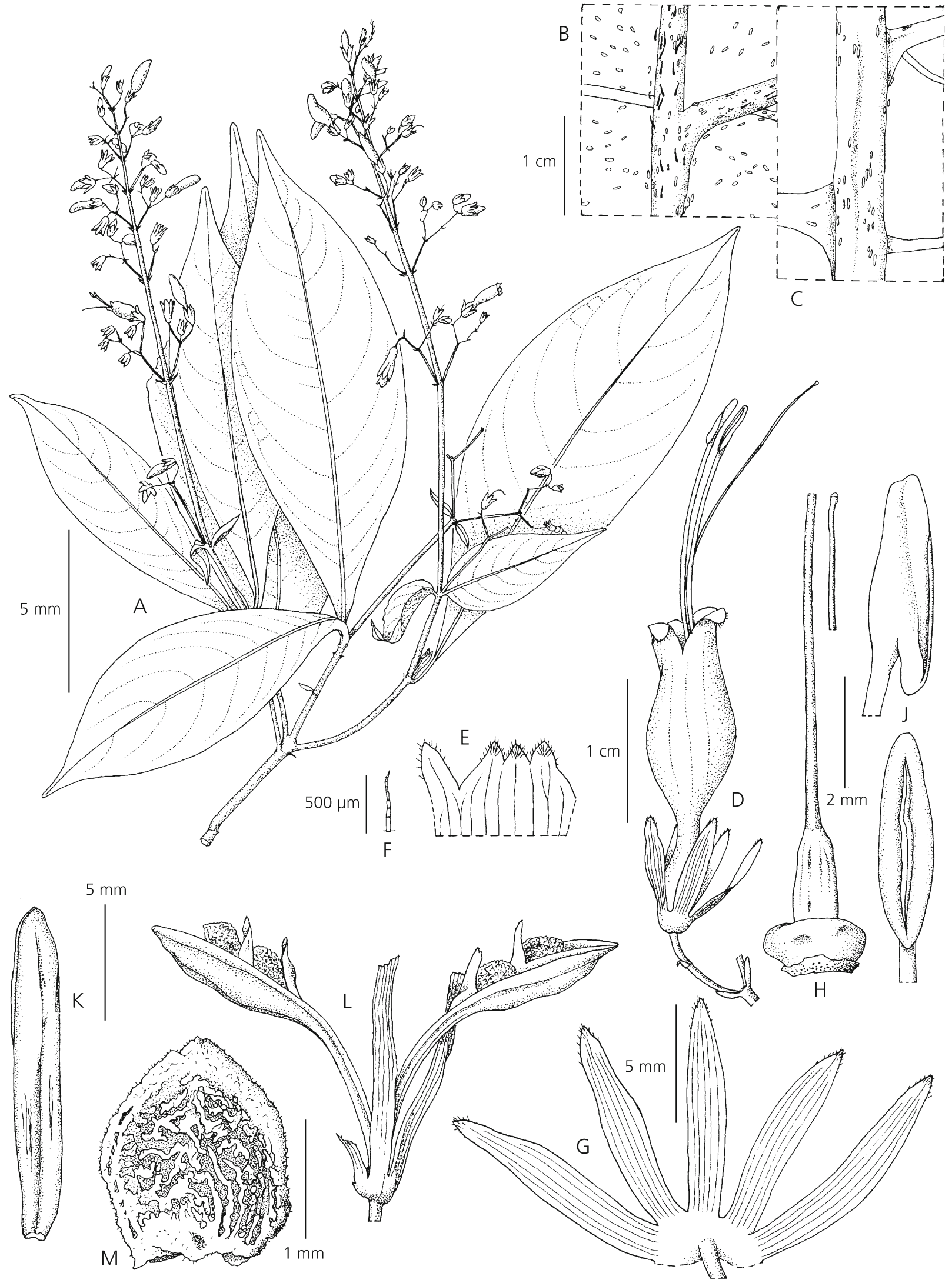

Fig. 2. Stenostephanus atrocalyx. A habit; B adaxial leaf surface; C abaxial leaf surface; D flower; E corolla lobes; $\mathrm{F}$ detail of hair from corolla lobe; G calyx opened out; $\mathrm{H}$ ovary and style; J anthers; K capsule; L capsule opened out to show seed; M seed. A - C from Sandeman 3680; D - M from Wasshausen et al. 593. DRAWN BY ANDREW BROWN. 


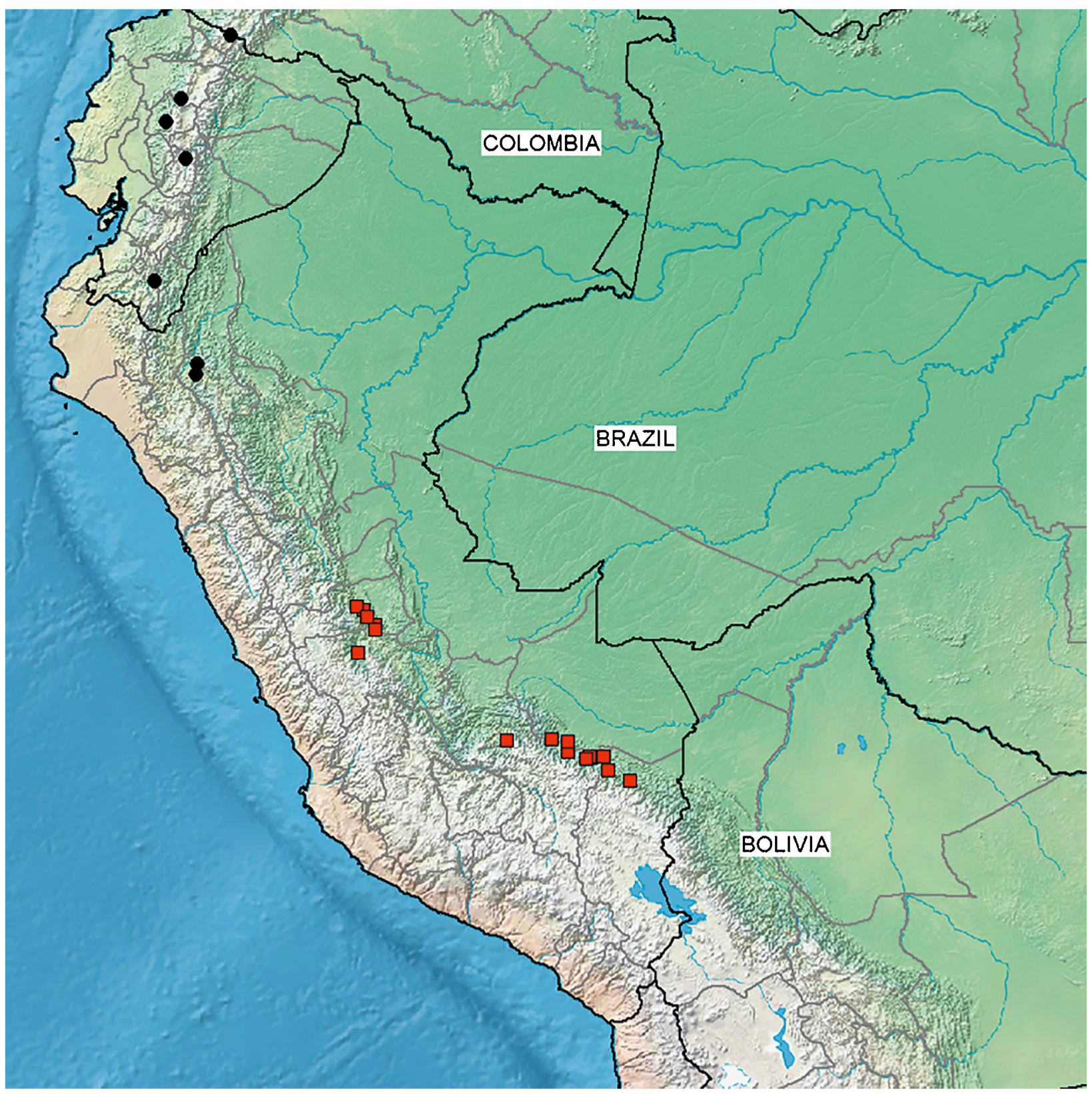

Map 2. Map of Peru and neighbouring countries showing distribution of Stenostephanus atrocalyx (red squares) and S. jamesonii (black circles).

probably the case with other tubular red-flowered species such as Stenostephanus jamesonii and S. cuscoensis.

Stenostephanus cuscoensis J.R.I.Wood, sp. nov. Type: Peru, Cusco, Lares Valley above Mantoc, 8 March 1929, A. Weberbauer 7917 (holotype F1849836, isotypes F605272, K, US2653737).

http:/ /www.ipni.org/urn:lsid:ipni.org:names:60479360-2
Robust isophyllous herb $1-2 \mathrm{~m}$ high; stems shortly appressed pubescent. Leaves petiolate; petioles $0.3-3 \mathrm{~cm}$, somewhat hispid-pubescent, diminishing in size upwards; lamina $4-26 \times 1.8-9.5 \mathrm{~cm}$, oblong-elliptic, shortly acuminate at both ends, margin entire, veins $7-10$ pairs, both surfaces thinly hispid-hirsute but densely so on the veins, adaxially usually with prominent cystoliths, abaxially paler. Inflorescence of solitary terminal unbranched racemes $12-20(-35) \mathrm{cm}$ long, rarely with short secondary spikes from the axils of the uppermost pair of leaves (which are subsessile and basally rounded); flowers opposite or 
arranged in subverticillate clusters along the rhachis, the clusters c. $1 \mathrm{~cm}$ distant below but nearly confluent apically; rhachis densely hispid-hirsute with large-celled, bulbousbased yellowish hairs, bracts sometimes leaf-like at base of spike, resembling the bracteoles upwards; bracteoles $3-5$ $\mathrm{mm}$, linear, hispid-hirsute; peduncles c. $3 \mathrm{~mm}$ long, simple or forked, hispid-hirsute; pedicels $0-2 \mathrm{~mm}$; calyx $5-9 \mathrm{~mm}$ long, hispid-hirsute, 5-lobed to near the base, the lobes slightly unequal, filiform, attenuate; corolla $2.1-2.7 \mathrm{~cm}$ long, subcylindrical, red or purplish, the exterior hirsute with short spreading hairs, the lobes short, subequal, rounded, $1-2.5 \mathrm{~cm}$ long; stamens exserted $10-14 \mathrm{~mm}$, filaments glabous, anthers $6 \mathrm{~mm}$ long; style thinly pilose, $2.5-3.5 \mathrm{~cm}$ long, persistent after the corolla has fallen; ovary densely hirsute with white hairs. Capsule $11-12 \times 2.5$ $\mathrm{cm}$, clavate, hirsute, 4-seeded; seeds $1.5 \times 1 \mathrm{~mm}$, lenticular, rugose. Fig. 3A - L.

RECOGNITION. Resembles Stenostephanus lobeliiformis Nees and S. lyman-smithii Wassh. in the elongate racemose inflorescence and tubular corolla with short lips but differs from both these species in the hirsute leaves (not glabrous to thinly pubescent on the veins), the larger corolla, $2.1-2.7 \mathrm{~cm}$ long (not $1.5-2 \mathrm{~cm}$ long), densely spreading (not finely appressed) pubescence on the exterior of the corolla and in the more finely filiform-attenuate calyx lobes.

HABITAT \& DISTRIBUTION. A plant of hill forest recorded mostly between 1800 - $1900 \mathrm{~m}$ in Andean Peru (Map 3). It is endemic to the Cusco region in the south of Peru. SPECIMENS EXAMINed. PERU. Cusco: Calca, Yanatile, camino hacia Lacco Yavero, $12^{\circ} 19^{\prime} \mathrm{S} 72^{\circ} 18^{\prime} \mathrm{W}, 1815 \mathrm{~m}$, 26 Feb. 2005, L. Valenzuela et al. 5234 (MO, US); Calca, entre Kukipata y San Pedro, 1200 - 2200 m, 26 July 1954, C. Vargas 10997 (US); Lares Valley above Mantoc, A. Weberbauer 7917 (F, K, US); La Convención, Ocobamba, Versalles, Santa Elena, 1246'37"S $72^{\circ} 16^{\prime} 58^{\prime \prime} \mathrm{W}, 1853 \mathrm{~m}, 21$ Nov. 2007, L. Valenzuela et al. 10343 (MO).

CONSERVATION STATUS. With an area of occupancy of $12,000 \mathrm{~km}^{2}$ and an extent of occurrence of $865.479 \mathrm{~km}^{2}$, based on Geocat, this species should be provisionally classified as Endangered (EN) according to IUCN guidelines. It is only known from four collections, two made more than 50 years ago and its forest habitat is vulnerable to clearance. Further studies are needed to confirm the classification but, unless further populations are found, a classification of CR (Critically Endangered) may prove to be more correct.

EPONYMY. This species is named "cuscoensis" after the Cusco region to which it is endemic.

Stenostephanus davidsonii Wassh. (Wasshausen 1999a: 285). Type: Bolivia, La Paz, $16.2 \mathrm{~km}$ SW of Yolosa towards Unduavi, 2440 m, 12 Nov. 1976, C. Davidson 4973 (holotype LAM).
Inflorescence branched, formed of lax axillary and terminal thyrses; bracteoles $2-4 \mathrm{~mm}$, filiform; sepals glandular-pilose, 9 - $14 \mathrm{~mm}$, linear-filiform; corolla white, c. $10-11 \mathrm{~mm}$ long, distinctly 2-lipped, glabrous or nearly so, the tube c. $5-6 \mathrm{~mm}$, the lips c. $4 \mathrm{~mm}$ long; capsule glabrous.

HABITAT \& DISTRIBUTION. Cloud forest in northern Bolivia and Peru at relatively high altitudes between about 2200 and $2800 \mathrm{~m}$. It is apparently more common in Bolivia than in Peru. Map 4.

SPECIMENS EXAMINED. PERU. Cusco: La Convención, Maranura, Mesa Pelada, 12³2'S 72²2'W, 2547 m, 20 April 2005, L. Valenzuela 5559 (US). Huánuco: Carpish, above Acomayo, 2800 m, 17 July 1964, P. C. Hutchison et al. 5945 (K, MO, UC).

Stenostephanus densiflorus J.R.I.Wood, sp. nov. Type: Peru, Ucayali, Coronel Portillo, Padre Abad, Cumbre de la Divisoria, 1500 - 1600 m, 8 Feb. 1978, J. Schunke V. 9864 (holotype US2949097; isotype US 2948849).

http://www.ipni.org/urn:lsid:ipni.org:names:60479361-2

Subshrub to $2 \mathrm{~m}$; stems dark green, glabrous. Leaves subsessile to shortly petiolate; lamina $10-31 \times 4-13$ $\mathrm{cm}$, oblong-elliptic, shortly acuminate, basally cuneate, sometimes decurrent onto a poorly differentiated petiole, margin slightly undulate, both surfaces glabrous or puberulent on abaxial veins, veins c. 11 pairs, adaxially with numerous cystoliths, abaxially pale; petioles $(0-) 0.5-5 \mathrm{~cm}$. Inflorescence a dense, manyflowered thyrse, $7-17 \times 6-7 \mathrm{~cm}$; bracts at base of thyrse resembling small, sessile leaves, pubescent; rhachis glabrous to tomentellous; bracts at branching points $6-12 \times 7-10 \mathrm{~mm}$, ovate, subrhomboid or obovate, diminishing in size upwards, green, persistent, glabrous or ciliolate; dichasia sessile; pedicels 5 $6 \mathrm{~mm}$; calyx 9 - $11 \mathrm{~mm}$, 5-lobed to base, lobes linear, acute, $0.75-1 \mathrm{~mm}$ wide; corolla $3-4 \mathrm{~cm}$ long, crimson, wine-red, dark red, indistinctly 2-lipped, the lips minutely puberulent, the upper lip subacute, entire c. 6 - $8 \mathrm{~mm}$ long, lower lip similar but 3toothed, the teeth triangular c. $1.25 \mathrm{~mm}$ long; stamens exserted, filaments glabrous, anthers $4 \mathrm{~mm}$, style glabrous, stigma globose, ovary glabrous. Capsule clavate, 12 - $13 \mathrm{~mm}$ long, glabrous; seeds lenticular c. $2.5 \mathrm{~mm}$ long (?immature). Fig. 4.

RECOGNITION. Amongst species found in Peru, Stenostephanus densiflorus is very distinct for the possession of two distinct characters - the very dense inflorescence and the prominent bracts at the main branching points of the thyrse. Similar bracts are found in a number of species such as $S$. lamprus 


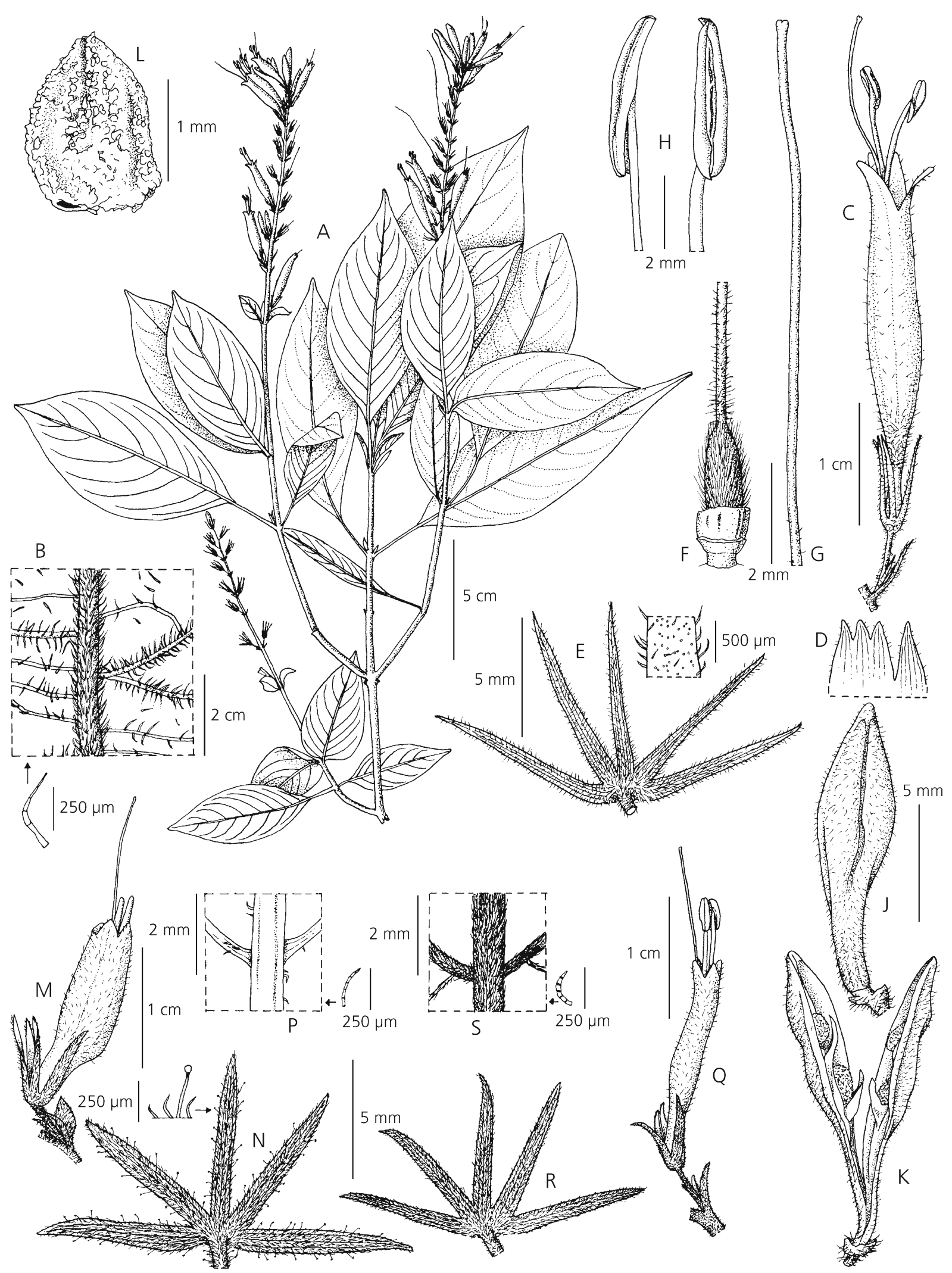

Fig. 3. A - L Stenostephanus cuscoensis. A habit; B abaxial leaf surface; C flower; D corolla lobes; E calyx opened out with detail of indumentum of lobe (inner face); F ovary and style; G style and stigma; $\mathrm{H}$ anthers; J capsule; K capsule opened to show seeds; L seed. M P S. lyman-smithii. M flower; N calyx opened out; P abaxial leaf surface. Q - S S. lobeliiformis. Q flower; R calyx opened out; S abaxial leaf surface. A - L from Weberbauer 7917; M - P from Wood et al. 14860; Q - S from Eiten et al. 6320. DRAWN BY ANDREW BROWN. 


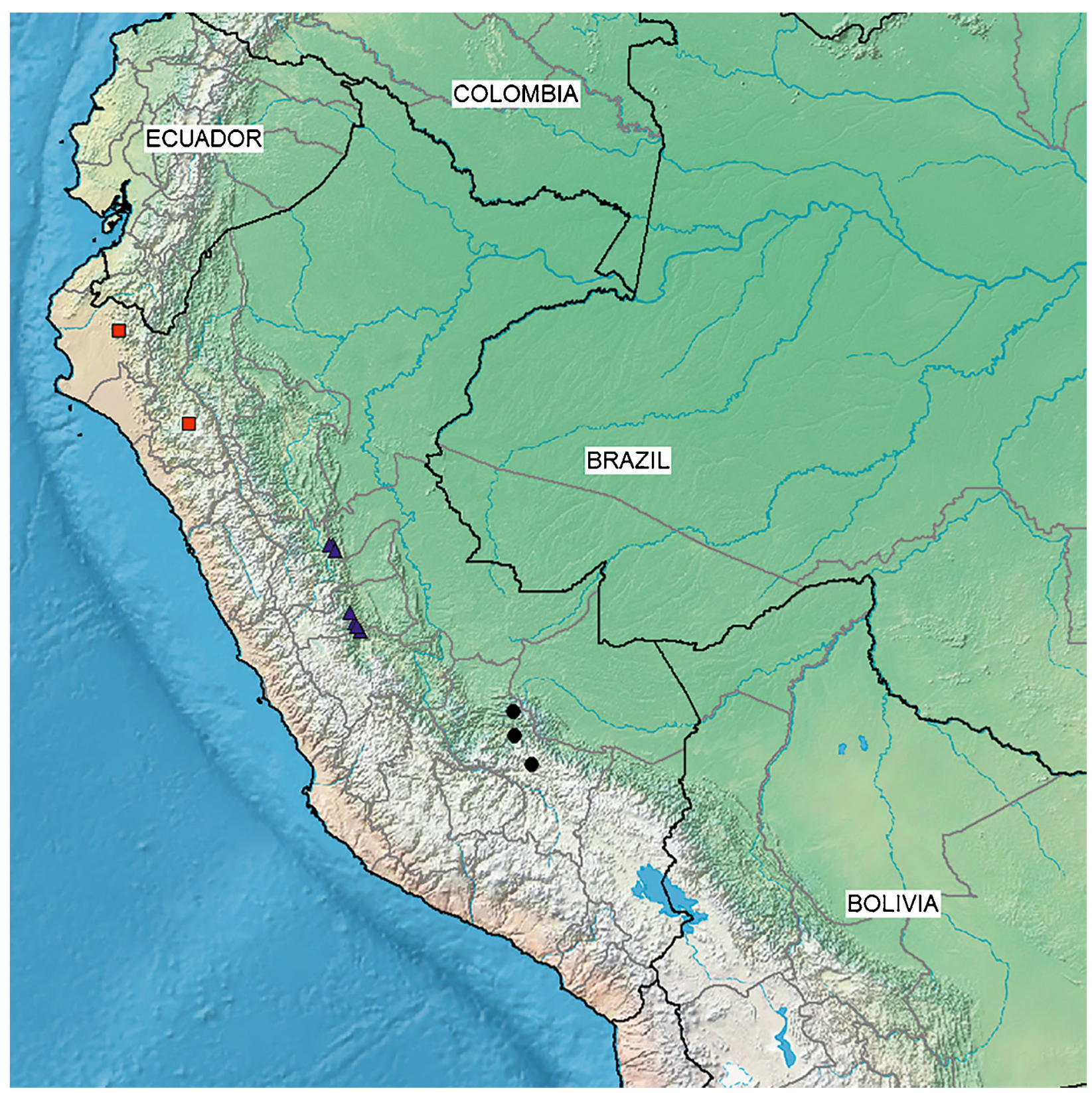

Map 3. Map of Peru and neighbouring countries showing distribution of Stenostephanus cuscoensis (black circles), S. densiflorus (blue triangles) and S. lasiostachyus (red squares).

(Leonard) J.R.I.Wood from Colombia or S. laxus (Wassh.) Wassh. from Ecuador, but $S$. densiflorus differs from most of these in the absence of a long, somewhat recurved upper lip as well as in the denser inflorescence. It is perhaps most similar to $S$. asplundii (Wassh.) Wassh. but the corolla is red, elongatetubular, not suburceolate, $3-4 \mathrm{~cm}$, not $18 \mathrm{~mm}$ long and minutely puberulent, not pilose.

HABITAT \& DISTRIBUTION. Moist hill forest 1200 - 1850 m 1150 - $1250 \mathrm{~m}$ in the Peruvian Andes. Endemic to Peru in the zone where Huánuco, San Martín and Ucayali meet, principally in the zone known as La Divisoria. Map 3.
SPECIMENS EXAMINED. PERU. Huánuco: Leoncio Prado, Divisoria, 1600 m, 7 Sept. 1946, F. Woytkowski 34495 (MO); ibid., Tingo María - Pucallpa road near Loreto [Ucayali] border, 1150 - 1250 m, 29 March 1977, A. Gentry 18816 (US); ibid., A. Gentry et al. 18831 (US); ibid., Hermilio Baldizan, Carretera Tingo María - Pucallpa, La Divisoria, 1600 m, 22 March 1980, M. Rimachi 5011 (US); ibid., $38 \mathrm{~km}$ E of Tingo María on road to Pucallpa, Divisoria, 9 $05^{\prime} \mathrm{S} 75^{\circ} 48^{\prime} \mathrm{W}, 1550 \mathrm{~m}, 18 \mathrm{Jan} .1987$, B. A. Stein Eु J. Kallunki3903 (MO, US). Pasco: Huancabamba, Cordillera Yanachaga, road from Oxapampa to Villa Rica, $10^{\circ} 40^{\prime} \mathrm{S}$ $75^{\circ} 20^{\prime} \mathrm{W}, 2100$ - $2500 \mathrm{~m}, 1 \mathrm{March}$ 1982, A. Gentry $\mathcal{E}^{\circ} D$. Smith 35853 (US); ibid., Quebrada Yanachaga, 10²3'58"S 


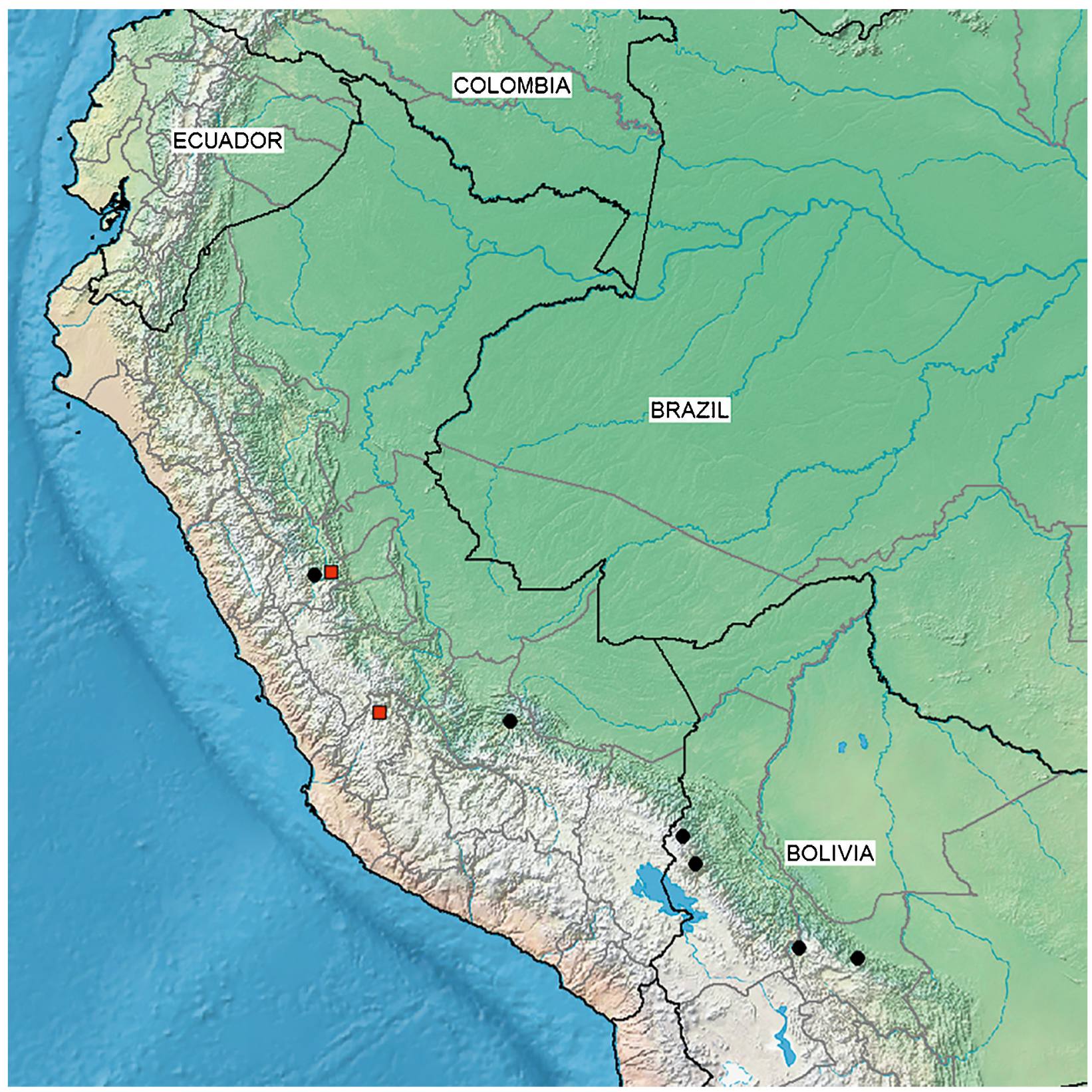

Map 4. Map of Peru and neighbouring countries showing distribution of Stenostephanus davidsonii (black circles) and S. macrolobus (red squares).

75²9'12"W, 2169 m, 9 Feb. 2004, R. Rojas et al. 1995 (MO, US); Oxapampa, $5 \mathrm{~km}$ SE of Oxapampa, property of Oswaldo Muller, $10^{\circ} 36^{\prime} \mathrm{S} 75^{\circ} 23^{\prime} \mathrm{W}, 1850$ m, 31 Jan. 1983, D. N. Smith 3151 (MO, US); ibid., Huanacabamba, P.N. Yanachaga-Chemillen, Sector Quebrada Yanachaga, $10^{\circ} 23^{\prime} 45^{\prime \prime S} 75^{\circ} 28^{\prime} 55^{\prime \prime W}, 2265$ m, 10 Feb. 2004, R. Vasquez 29229 (MO, US); ibid., Villa Rica, Santa Polonia Alta, 1500 m, 27 Feb. 1986, H. van der Werff et al. 8294 (MO, US). San Martín: Divisoria, km 59 from Tingo María towards Pucallpa, 1600 m, 17 Nov. 1949 - 15 Jan. 1950, H. A. Allard 21776 (US). Ucayali: Coronel Portillo, Divisoria, entre Pucallpa and Tingo María, 1200 - 1400 m, 14 Aug. 1946, R. Ferreyra 1006 (US); ibid., Padre Abad,
Cumbre de la Divisoria, 1500 - 1600 m, 8 Feb. 1978, J. Schunke 9864 (US).

CONSERVATION STATUS. With an area of occupancy of $32,000 \mathrm{~km}^{2}$ and an extent of occurrence of 1724.075 $\mathrm{km}^{2}$, based on Geocat, this species should be provisionally classified as Endangered (EN) according to IUCN guidelines. Although hill forest is vulnerable to clearance, some populations lie within the Yanachaga-Chemillén National Park, Tingo María National Park and the new Sierra del Divisor National Park and enjoy legal protection.

EPONYMY. This species is named "densiflorus" because of the very dense inflorescence. 


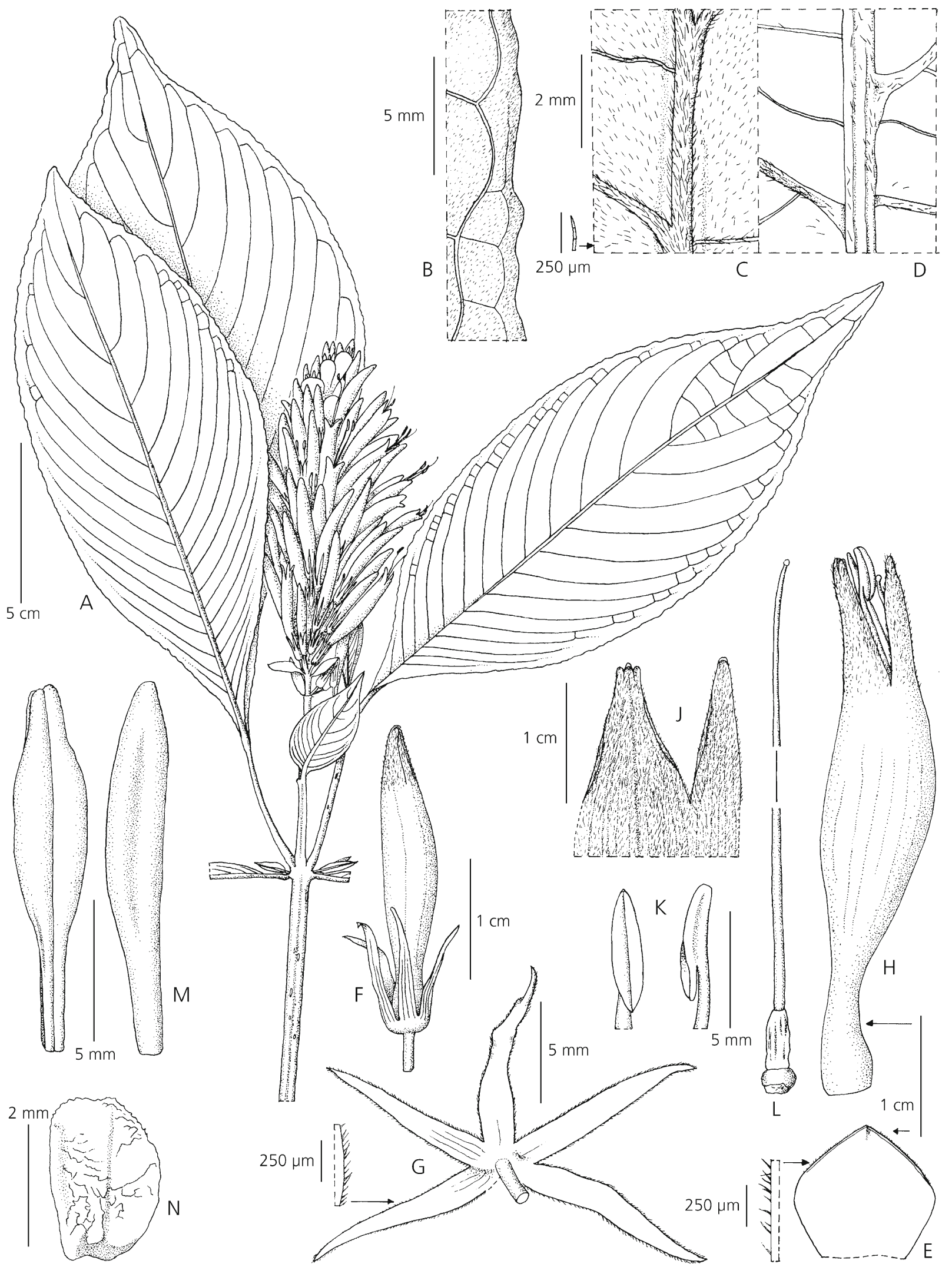

Fig. 4. Stenostephanus densiflorus A habit; B leaf margin; C adaxial leaf surface; D abaxial leaf surface; $E$ floral bract and inset of margin; $\mathrm{F}$ calyx and flower bud; $\mathrm{G}$ calyx opened out with inset of margin; $\mathrm{H}$ apex of flower bud; J corolla lobes; $\mathrm{K}$ anthers; $\mathrm{L}$ ovary and style; M capsules; N seed (immature). A - D from Allard 21776; E- G, H, L from Ferreyra 1006; J, K, M from Schunke 9864; N from Gentry et al. 18831. DRAWN BY ANDREW BROWN. 
Stenostephanus jamesonii (Wassh.) Wassh. (Wasshausen 1999b: 953).

Hansteinia jamesonii Wassh. (Wasshausen 1985: 203). Type: Ecuador, West of Pichincha, W. Jameson 8 (holotype E00259188, isotypes BM, G, NY, P, W).

Nearly glabrous perennial herb. Inflorescence a very lax, diffuse thyrse $5-30 \times 15 \mathrm{~cm}$, the branches with scattered stalked glands but otherwise glabrous; calyx lobes 3-4 mm, linear, acuminate, corolla $1.5-1.8 \mathrm{~cm}$ long, red, suburceolate with short subequal lobes c. $2 \mathrm{~mm}$ long; capsule glabrous.

HABITAT \& DISTRIBUTION. Cloud forest at altitudes of 2300 - $2750 \mathrm{~m}$. Relatively common in Ecuador (Wasshausen 2013), extending into the extreme north of Peru. Map 2.

SPECIMENS EXAMINED. PERU. Amazonas: Bagua, Cordillera Colán, SE of La Peca, 9000 ft, 25 Sept. 1978, P. Barbour 3581 (MO, US); Cordillera Colan, SE of La Peca, 7500 - 7900 ft, 12 Oct. 1978, P. Barbour 4000 (US). NOTE. Stenostephanus jamesonii is morphologically very close to $S$. charitopes (Leonard) J.R.I.Wood from Colombia.

Stenostephanus lasiostachyus Nees (1847: 311). Type: Venezuela, Caracas, Moritz 258 (holotype $\mathrm{B} \dagger$, photo F0BN008884).

Leaves absent at anthesis. Inflorescence branched, spicate, densely glandular-pilose; pedicels $0-5 \mathrm{~mm}$, bracteoles linear, somewhat persistent; corolla ventricose, suburceolate, 10 - 12 mm long, golden-yellow with red markings, glandular-pilose; capsule $1-1.2 \mathrm{~cm}$, shortly glandular-pubescent.

HABITAT \& DISTRIBUTION. A plant with a unique disjunct distribution. It is widespread in Andean Venezuela, where it is recorded from five states (Hokche et al. 2008) but is absent from Colombia and Ecuador. The two records from northern Peru are, therefore, very disjunct from the main population, although the identification appears to be correct. In Peru, it is a rare species of "forest shade" between 1200 and 1900 $\mathrm{m}$ in Cajamarca and Piura. Map 3.

SPECIMENS EXAMINED. PERU. Cajamarca: Hualgayoc, Hac. Taulis, 1900 m, 29 Aug. 1964, P. C. Hutchison Eे K. von Bismarck 6335 (K, MO, UC). Piura: Ayavaca; below Frias, 1200 m, May 1912, A. Weberbauer 6421 (F). NOTE. The epithet of this species is commonly misspelt lasiostachys instead of the original lasiostachyus.

Stenostephanus longistamineus (Ruiz $\mathcal{E}$ Pav.) V.M.Baum (1982: 433).

Justicia longistaminea Ruiz \& Pav. (Ruiz \& Pavon 1798:

8). Type: Peru, lectototype MA815569, designated here, isotypes BM, G00236603, MA815570, OXF).
Thyrsacanthus longistamineus (Ruiz \& Pav.) Nees (1847: 326).

Stenostephanus bolivianus Rusby (1927: 366). Type: Bolivia, Ixiamas, M. Cardenas 1905 (holotype NY00278291, isotype K000529043).

Stenostephanus thyrsoides Lindau (1914: 198). Type: Brazil, Alto Acre, Paraguassu, E. Ule 9795 (holotype ? $\mathrm{B} \dagger$, isotypes K000529044, L2841863, U0000131, UC492971).

Herb to subshrub $0.4-1.5 \mathrm{~m}$; stems quadrangular, pubescent or glabrous. Leaves petiolate; petioles $0.3-$ $2.5 \mathrm{~cm}$, pubescent; lamina $8-30 \times 2.5-15 \mathrm{~cm}$, elliptic, shortly acuminate, base attenuate and shortly decurrent onto the petiole, veins 10 - 12 pairs, margins undulate to irregularly crenate, adaxially glabrous to subglabrous but with scattered hair bases and short hairs, abaxially paler, glabrous or pubescent, especially on the veins. Inflorescence a pedunculate, hirsute, terminal thyrse $4-12(-20) \times 2-5 \mathrm{~cm}$, sometimes spike-like; rhachis densely yellow-green hirsute with short, spreading hairs, bracts at base of inflorescence resembling small, pubescent, sessile leaves; dichasia dense, many-flowered, c. $1.5 \mathrm{~cm}$ long, up to 20 arranged along the rhachis, c. $2 \mathrm{~cm}$ distant below but imbricate above, bracteoles lanceolate-deltoid, c. $2 \times$ $1.5 \mathrm{~mm}$ long; peduncles, secondary peduncles and pedicels very short, $2-3 \mathrm{~mm}$, pubescent; calyx 4 $5 \mathrm{~mm}$ long, the basal part c. $1 \mathrm{~mm}$ long, the lobes 3 $3.5 \mathrm{~mm}$, lanceolate-deltoid, acute, glabrous or puberulous; corolla $1.6-3 \mathrm{~cm}$ long, pink, "fuchsia" or pinkish-purple, glabrous or pubescent especially towards the apex, basal tube $2-2.5 \mathrm{~cm}$ long, weakly 2lipped, the upper lip 3-5 mm long, entire, erect, the lower lip shorter, unequally 3-lobed, the lateral lobes longer than the central lobe, $1-2 \mathrm{~mm}$ long; stamens exserted 5 - $20 \mathrm{~mm}$, anthers $3 \mathrm{~mm}$ long; style glabrous, stigma subglobose. Capsule $15 \times 2.25 \mathrm{~cm}$, weakly clavate, glabrous, 4-seeded; seeds $1.5 \times 1 \mathrm{~mm}$, lenticular, reticulate. Fig. 5.

NOMENCLATURE \& TYPIFICATION. The epithet longistaminea (with "e") was inexplicitly changed to longistaminus (without "e") by Baum (1982) when making the combination in Stenostephanus. Most recent publications have followed this spelling but the original, as used by Ruiz \& Pavon, should be used. This species is sometimes filed, as in Madrid, under the name Odontonema longistamineum (Ruiz \& Pav.) Kuntze, but this appears to be a nomen nudum as it was never published. The photograph of the Berlin specimen of Stenostephanus thyrsoides at the Field Museum (FOBN008836) does not appear to be an image of the type as it is labelled as Weberbauer 6798. It is possible that the holotype was never at Berlin although there is nothing to indicate this in the protologue. 


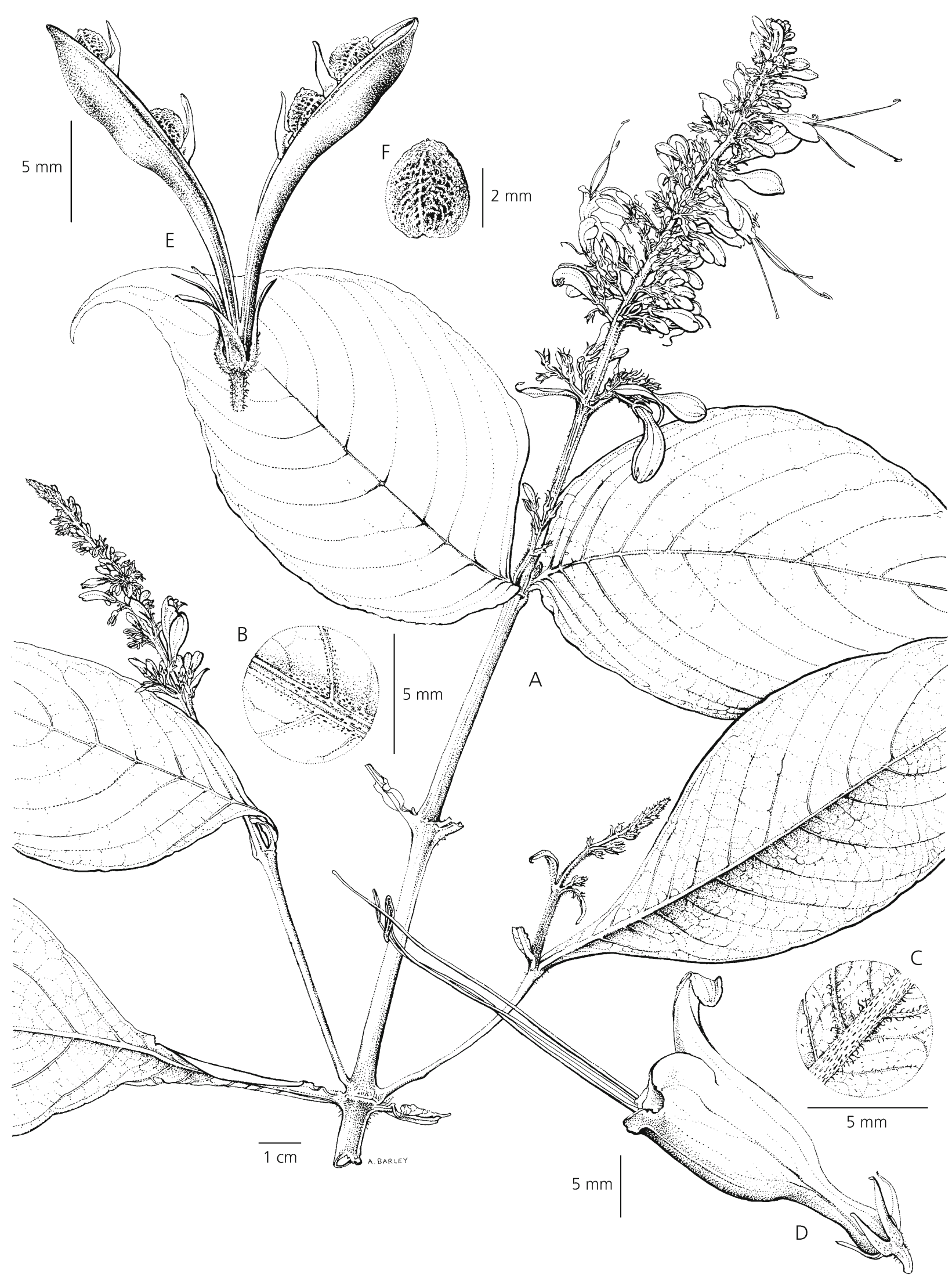

Fig. 5. Stenostephanus longistamineus A habit; B adaxial leaf surface; C abaxial leaf surface; D corolla and calyx; E capsule; F seed. A - C from Stork \& Horton s.n.; D - E from Wasshausen \& Encarnación 749. DRAWN BY ANITA BARLEY. 
NOTE. Stenostephanus longistamineus is an exceptionally widespread species, occurring in three countries (Map 5), and is also exceptionally variable. Variation is most marked in the form of the inflorescence (subspicate to a lax thyrse), in the size of the inflorescence (short and much exceeded by the subtending leaves, to elongate and much exceeding the subtending leaves), inflorescence indumentum (glabrous to densely hirsute) and to a lesser extent corolla size and indumentum. I originally thought several distinct species were involved but examina- tion of a large number of specimens revealed overlapping characters and overlapping distribution ranges (Map 5). I have consequently recognised three varieties which are readily recognised although there exist specimens which are difficult to assign. I suspect $S$. wallnoeferi may also prove to be only a variety of $S$. longostamineus but as the corolla size and distribution range (Map 5) lie somewhat outside that of $S$. longistamineus, I have maintained it as a distinct species. I recognise the following three varieties:

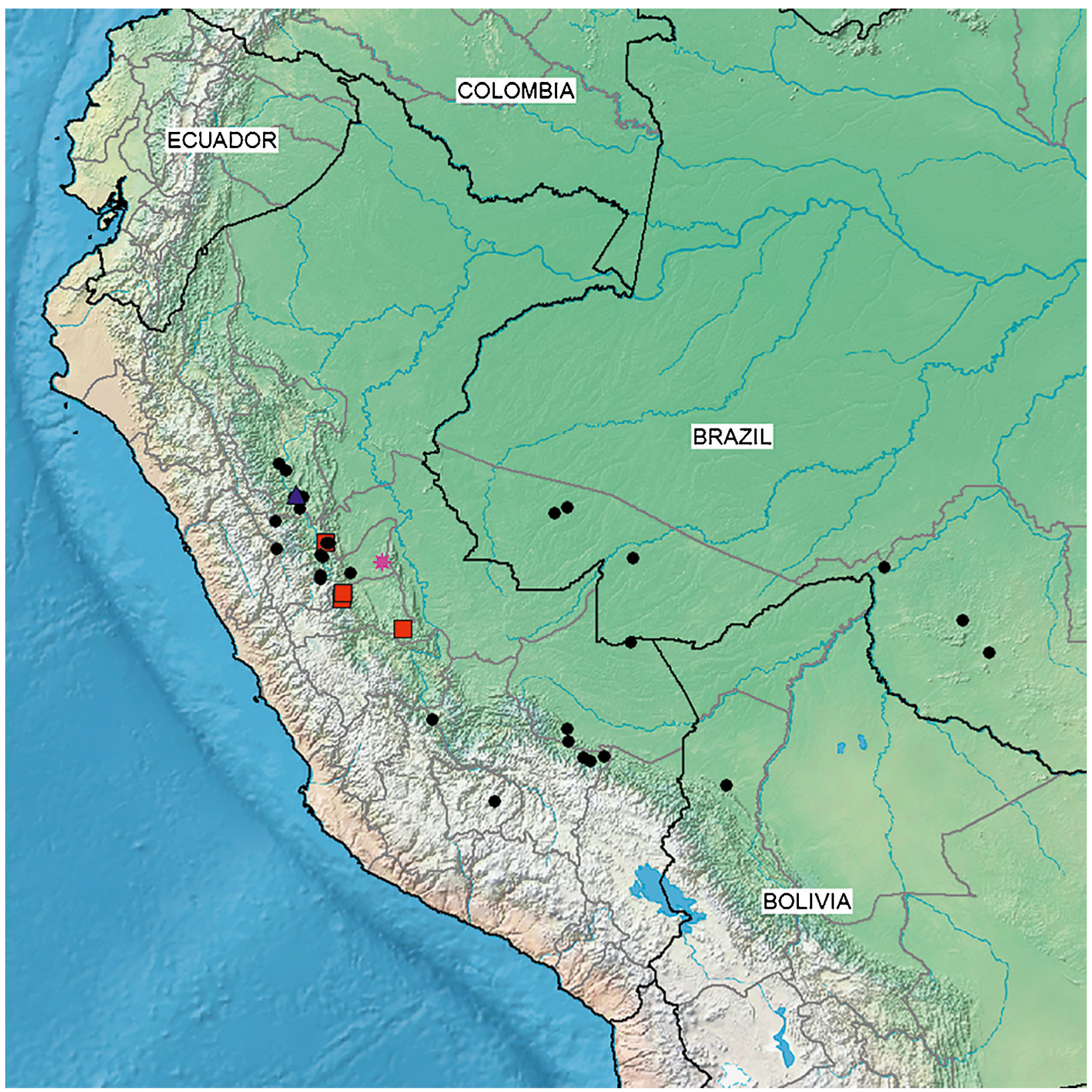

Map 5. Map of Peru and neighbouring countries showing distribution of Stenostephanus wallnoeferi (pink star), S. longistamineus var. longistamineus (black circles), var. angustissimus (blue triangle) and var. hirtiflorus (red squares). 


\section{var. longistamineus}

Inflorescence a usually robust lax thyrse, up to $12 \mathrm{~cm}$ long, equalling or overtopping the subtending leaves, the branches usually pubescent but sometimes glabrous or nearly so. Corolla $2-3 \mathrm{~cm}$ long, the tube $2-$ $2.5 \mathrm{~cm}$ long, the lips $3-5 \mathrm{~mm}$ long. Fig. 5 .

HABITAT \& DISTRIBUTION. Lowland rainforest in the eastern Andean foothills and in the upper Amazon basin in western Brazil, northwestern Bolivia and south east Peru between about 350 and 800 m. Map 5. SPECIMENS EXAMINED. PERU. Cusco: Río Arasa, NE of Cusco, 3500 ft, Jan. 1943, C. Sandeman 3649 (K); La Convención, along road between Colonizacion Pichari and San Francisco de Apurimac, 575 m, 14 June 1975, D. C. Wasshausen E F Encarnación 553 (K, MO); ibid., Cordillera Vilcabamba, opposite Hac. Luisiana, 680 m, 30 May 1975, D. C. Wasshausen Ẽ F. Encarnación 492 (K, MO); ibid., opposite Hac. Luisiana, 680 m, 30 May 1975, D. C. Wasshausen Ẽ F. Encarnación 493 (K, MO); ibid., Echarati Cashiari-3 well site, $5 \mathrm{~km} \mathrm{~S}$ of Camisea R.,

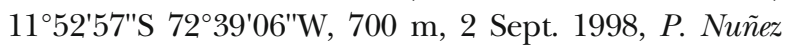
et al. 23881 (US); Quispicanchis, trail, $25 \mathrm{~km} \mathrm{SW}$ of Quicemil, 1340 m, 8 Oct. 1976, D. C. Wasshausen E F. Encarnación, 749 (K, MO); ibid., Cerro Camanti, 13 17'19"S 7046'27"W, 880 m, L. Valenzuela et al. 8641 (MO, OXF). Huánuco: Pampamarca, Ruiz Ẽ Pavon s.n. (BM, MA, OXF); Rio Huallaga at Tingo María, 4 Oct. 1972, T. B. Croat 21506 (MO); Left bank of Río Huallaga above Cayumba, 798 m, Ynes Mexia 8311 (BM, K, MO); Tingo María (Huallaga), 2000 ft, June 1938, C. Sandeman 123 (K); Tingo María (Huallaga), $2000 \mathrm{ft}$, Nov. 1942, C. Sandeman 3479 (K); Tingo María, Valley of Río Huallaga, 700 m, 24 Oct. 1938, H. E. Stork Eं O. B. Horton 9485 (K, UC); Leoncio Prado, Rupa Rupa, Calpar Bella, Cueva de Los Huarinos, 700 - 900 m, 29 June 1976, J. Schunke-Vigo 9447 (MO); ibid., Cueva de las Pavas, 8 km S of Tingo María, 9 21'S 75 57'W, 700 m, 17 Jan. 1987, B. A. Stein et al. 3887 (MO); ibid., $38 \mathrm{~km}$ E of Tingo María on road to Pucallpa, La Divisoria, $9^{\circ} 05^{\prime} \mathrm{S} 75^{\circ} 48^{\prime} \mathrm{W}, 1550$ m, B. A. Stein Ẽ J. Kallunki 3907 (MO); ibid., Pachitea, Codo de Pozuzo, $9^{\circ} 40^{\prime} \mathrm{S} 75^{\circ} 25^{\prime} \mathrm{W}, 18$ Oct. 1982, R. Foster 9270 (F, MO). Madre de Dios: Río Acre, Seringal Auristella, April 1911, E. Ule 9795 (K); $8 \mathrm{~km} \mathrm{~N}$ of Salvacion on road to Shintuya, $500 \mathrm{~m}$, 29 June 1978, A. Gentry et al. 23648 (MO); Pantiacolla, Serrania across Río Alto Madre de Dios from Shintuya, 450 - 650 m, 28 Oct. 1979, A. Gentry et al. 27278 (MO); P.N. Manu, Est. Pakitza, 350 m, 11 Nov. 1980, R. B. Foster 5734 (F); ibid., Atalaya, Vic. Hac. Amazonia, $2-3 \mathrm{~km}$ W of village across Río Alto Madre, $12^{\circ} 55^{\prime} \mathrm{S} 71^{\circ} 12^{\prime} \mathrm{W}, 500$ - $600 \mathrm{~m}, 12$ Dec. 1983, R. Foster E T T. Wachter 7399 (MO). San Martín: Tocache Nuevo - Juanjui, $96 \mathrm{~km} \mathrm{~N}$ of Tocache and $84 \mathrm{~km}$ S of Juanjui, $7^{\circ} 41^{\prime} \mathrm{S} 76^{\circ} 40^{\prime} \mathrm{W}, 600 \mathrm{~m}, 8$ April 1984, T. B. Croat 58007 (MO); Mariscal Cáceres, Tocache Nuevo, camino al pueblo Tocache Viejo, 17 Jan. 1970,
J. Schunke-Vigo 3727 (K, MO); ibid., Tocache Nuevo, Río de la Plata, $8^{\circ} 10^{\prime} \mathrm{S} 76^{\circ} 25^{\prime} \mathrm{W}, 550$ - $650 \mathrm{~m}$, 2 Nov. 1980, T. B. Croat 51008 (MO); Uchiza, Sanja Seca de Tipishca, 8 km de Progreso, 500 - 550 m, 30 July 1974, J. SchunkeVigo 7904 (MO); Mariscal Cáceres, Tocache Nuevo, Río de La Plata, 550 - 700 m, 12 Aug. 1980, J. Schunke-Vigo 12143 (MO). Ucayali: Coronel Portillo, Cordillera Azul, km 64, Tingo María-Pucallpa, 1 km E of Puente Cholon, 600 m, 4 June 1981, K. Young E G. Sullivan 678 (MO) immature; ibid.; Boquerón Pass, between Tingo María and Pucallpa, $480 \mathrm{~m}, 19$ June 1982, D. C. Wasshausen $\mathcal{E}^{\circ}$ O. Tovar 1270 (K, MO); Rio Previsto, Puente Hidayaca, $25.7 \mathrm{~km} \mathrm{~W}$ of Aguaytia 9 $04^{\prime} 28^{\prime \prime S} 75^{\circ} 41^{\prime} 13^{\prime \prime W}, 2015 \mathrm{ft}$ [614 m], 22 Jan. 2017, E. Tripp E N. Medina 6796 (COLO, K).

NOTE. The type variety is far from constant in the size of the inflorescence or corolla; J. Schunke-Vigo 3727, for example, has exceptionally small flowers.

var. angustissimus J.R.I.Wood, var. nov. Type: Peru, San Martin, Tocache Nuevo, Quebrada de Huaquisha, right bank of Río Huallaga, 14 Dec. 1981, T. Plowman, J. Schunke-Vigo E $\mathcal{F}^{2}$ P. M. Rury 11397 (holotype K).

http:/ /www.ipni.org/urn:lsid:ipni.org:names:60479363-2

Perennial subshrub to $1 \mathrm{~m}$; stems glabrous. Leaves shortly petiolate; lamina $8-20 \times 2.5-9 \mathrm{~cm}$, oblongelliptic, acuminate, basally attenuate, margin entire to obscurely crenulate, both surfaces glabrous, paler beneath; petioles $0-4 \mathrm{~mm}$. Inflorescence a terminal spike-like thyrse $20 \mathrm{~cm}$ long with > 20 verticels along the rhachis; rhachis thinly pubescent; dichasia subsessile, c. $1 \mathrm{~cm}$ apart but becoming confluent above, bracteoles $2 \times 0.5 \mathrm{~mm}$, lanceolate, acuminate; pedicels simple, subglabrous to minutely puberulent, 2 - $3 \mathrm{~mm}$ long; calyx $3.5-4 \mathrm{~mm}$, glabrous, lobes narrowly lanceolate, acuminate; corolla curved, $2.2 \mathrm{~cm}$, light red-violet, glabrous, cylindrical for c. $9 \mathrm{~mm}$, then widened to $6 \mathrm{~mm}$ but not narrowed at mouth; upper lip entire, acute, lanceolate, $5 \mathrm{~mm}$ long, lower lip 3-toothed; stamens exserted c. 2 cm. Fig. 6.

RECOGNITION. Like Stenostephanus longistamineus var. longistamineus but spikes c. $20 \mathrm{~cm}$ long with $>20$ verticillasters far overtopping leaves; dichasia subsessile or flowers borne on unbranched pedicels; calyx glabrous and corolla tube with a relatively long basal part.

HABITAT \& DISTRIBUTION. Only certainly known from the type collection made in primary lowland forest near Tocache Nuevo in Peru. Map 5.

SPECIMENS EXAMINED. PERU. San Martin: Tocache Nuevo, Quebrada de Huaquisha, right bank of Río 


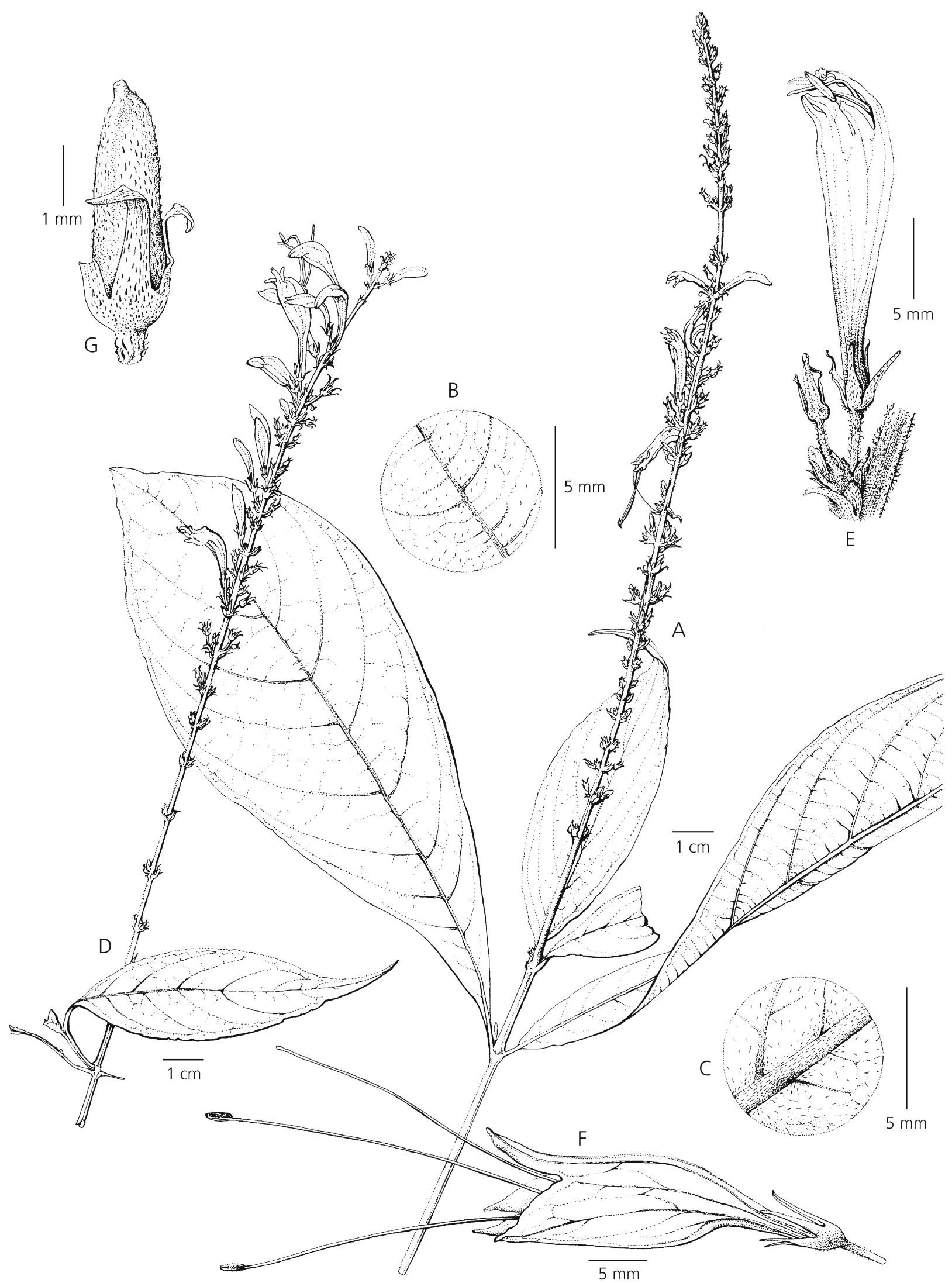

Fig. 6. Stenostephanus longistamineus var. angustissimus. A habit; B adaxial leaf surface; C abaxial leaf surface; D inflorescence; E inflorescence branch with bud, calyx and bracteoles; F flower showing corolla, stamens, style and calyx; G immature capsule. From T. Plowman et al. 11397. DRAWN BY ANITA BARLEY. 
Huallaga, 500 - 600 m, 14 Dec. 1981, T. Plowman et al. 11397 (K).

CONSERVATION STATUS. With a single collection and no details about the plant's frequency or of threats to its habitat, this variety can only be categorised as Data Deficient (DD) within IUCN guidelines.

NOTE. No other collection matches the type exactly. Sobrevila Eं Foster 1948 and Gentry et al. 25711 approach it in the near glabrous calyx and subspicate inflorescence but both have a more hirsute rhachis and the spikes are very short, < $5 \mathrm{~cm}$ long. Most interesting is Schunke-Vigo 11033, which has a narrow, elongate inflorescence $20 \mathrm{~cm}$ in length with a glabrous calyx, but it is more obviously racemose than spicate and is clearly intermediate between var. angustissima and var. longistamineus. These somewhat similar specimens, which are not considered paratypes, are listed below:

PERU. Madre de Dios: Río Manu, Cocha Juarez, 350 m, 15 Oct. 1987, C. Sobrevila E R R. Foster 1948 (US); San Martín, Mariscal Caceres, Fundo Curareland, near Tinanta, 20 km NW Tocache, 500 m, 14 March 1979, A. Gentry et al. 25711 (F, US); ibid., Tocache Nuevo, 400 - 700 m, 1979, J. Schunke-Vigo 11033 (MO).

var. hirtiflorus J.R.I.Wood, var. nov. Type: Peru, Gran Pajonal, $2-3 \mathrm{~km} \mathrm{~N}$ of Chequitavo, $10^{\circ} 45^{\prime} \mathrm{S} 74^{\circ} 23^{\prime} \mathrm{W}$, 1200 m, 21 Sept. 1983, D. N. Smith 5122 (holotype MO3518909, isotype US33123753).

http://www.ipni.org/urn:lsid:ipni.org:names:60479364-2

Herb to $1.5 \mathrm{~m}$; stem pubescent. Leaves petiolate; petioles $0.3-2.5 \mathrm{~cm}$, pubescent; lamina $8-25 \times 2.5-10 \mathrm{~cm}$, elliptic, shortly acuminate, base attenuate and shortly decurrent onto the petiole, adaxially subglabrous but with scattered hair bases and short hairs, abaxially paler, pubescent, more densely so on the veins. Inflorescence a hirsute terminal thyrse $4-10 \times 2-5 \mathrm{~cm}$, noticeably shorter than the upper leaves, rhachis densely yellowgreen hirsute with short, spreading hairs, bracts at base of inflorescence resembling small, pubescent, sessile leaves; dichasia dense, many-flowered, c. $1.5 \mathrm{~cm}$ long c. $2 \mathrm{~cm}$ distant below but imbricate above, bracteoles lanceolate-deltoid, c. $2 \mathrm{~mm}$ long; peduncles, secondary peduncles and pedicels very short, $2-3 \mathrm{~mm}$, pubescent; calyx $4-4.5 \mathrm{~mm}$ long, the lobes $3-3.5 \mathrm{~mm}$, lanceolatedeltoid, acute, very shortly hirsute; corolla $1.6-2 \mathrm{~cm}$ long, pink, "fuchsia" or pinkish-purple, pubescent especially towards the apex, weakly 2-lipped, the upper lip 3 $3.5 \mathrm{~mm}$ long, entire, the lower lip shorter, 3-lobed,; stamens exserted $5 \mathrm{~mm}$. Fig. 7 .

RECOGNITION. Distinguished from var. longistamineus by the shorter terminal inflorescences $(<10 \mathrm{~cm}$ long) which are overtopped by the subtending leaves and smaller corolla (15 - $20 \mathrm{~mm}$ long, not $20-30 \mathrm{~mm}$ ), which is pubescent apically (not completely glabrous). HABITAT \& DISTRIBUTION. In montane rain forest between 1100 and $1780 \mathrm{~m}$, so growing at altitudes much higher than the other varieties. It is endemic to Peru and known essentially from three localities, one in Huánuco and two in Pasco. Map 5.

SPECIMENS EXAMINED. PERU. Huánuco: Cordillera Azul, $43 \mathrm{~km}$ E of Tingo María on road to Pucallpa, 5650 5850 ft, 21 Nov. 1979, C. Davidson E J. Jones 9414 (F, US); Pasco: Oxapampa, Pozuzo, June 1860, R. Pearce 529 (K); ibid., Pozuzo, Puesto de Control Huampal, 10¹1'S 75³4W, 1100 m, 12 Aug. 2003, R. Rojas 1215 (MO, US); ibid., Pozuzo, Puesto de Control Huampal, R. Rojas 1239 (MO, US); ibid., Gran Pajonal, $2-3$ km $\mathrm{N}$ of Chequitavo, $10^{\circ} 45^{\prime} \mathrm{S} 74^{\circ} 23^{\prime} \mathrm{W}, 1200 \mathrm{~m}, 21$ Sept. 1983, D. N. Smith 5122 (MO, US); ibid., P.N. Yanachaga, El Huampal, 10¹1'S 75³4'W, 1200 m, 29 June 2003, H. van der Werff et al. 17855 (US).

CONSERVATION STATUS. With an area of occupancy of $16,000 \mathrm{~km}^{2}$ and an extent of occurrence of 6879.650 $\mathrm{km}^{2}$, based on Geocat, this species should be tentatively classified as Endangered (EN) based IUCN guidelines. The extent of occupancy might suggest it is merely vulnerable but there are few collections. Although montane forest is vulnerable to clearance, the populations at Huampal lie within the YanachagaChemillén National Park and enjoy legal protection.

NOTE. This variety is quite varied in corolla indumentum. In the type, the whole corolla is pubescent on the exterior whereas in the other cited collections the corolla is only pubescent towards the apex, sometimes sparsely so. This suggests that this variety intergrades with var. longistamineus, something confirmed by the existence of two specimens at $\mathrm{MO}$ from near the type locality of var. hirtiflora (L. Valenzuela E J. L. Mateo 13397 and R. Rojas et al. 4147), which appear to belong to var. longistamineus.

Stenostephanus macrolobus (Lindau) J.R.I.Wood (2009: 53)

Habracanthus macrolobus Lindau (1922: 143). Type: Peru, Huancavelica, A. Weberbauer 6580 (holotype $\mathrm{B} \uparrow$, isotypes F628197, GH00093979, MOL00005709, US00137011, US00137012).

Inflorescence formed of a well-branched rather lax thyrse $25 \times 8 \mathrm{~cm}$, corolla and capsule densely hirsute with short spreading hairs; calyx lobes filiform, c. $6 \mathrm{~mm}$ long, but accrescent to $10 \mathrm{~mm}$; corolla tube c. $9 \mathrm{~mm}$ long, the lobes of lower lip free c. $3 \mathrm{~mm}$ long

HABITAT \& DISTRIBUtION. Endemic to Peru. Nothing is known of its habitat, but it presumably grew in forest. Map 4. 


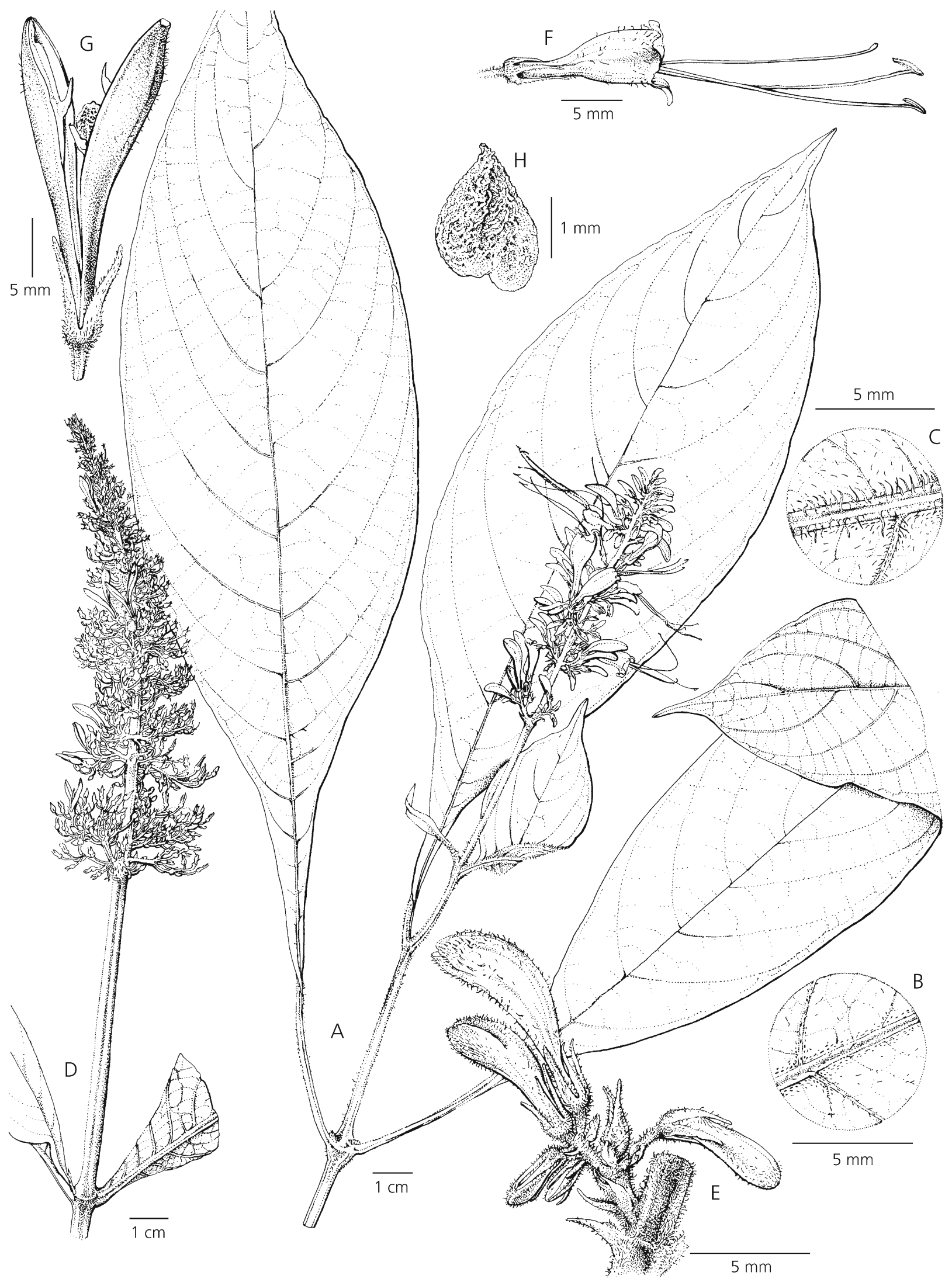

Fig. 7. Stenostephanus longistamineus var. hirtiflorus A habit; B adaxial leaf surface; C abaxial leaf surface; D fruiting inflorescence; E inflorescence branch with bud, calyx and bracteoles; F flower showing corolla, stamens, style and calyx; G capsule; H seed. A - C, E - F from D.N. Smith 5122; D, G - H from Rojas et al. 1215. DRAWN BY ANITA BARLEY. 
SPECIMENS EXAMINED. PERU. Huancavelica: Tajacaya, Left side of Río Bernardo, 6 April 1913, A. Weberbauer 6580 (isotype F); Huánuco: Muña, 1923, A. Weberbauer, 3909 (F); ibid., A. Weberbauer 4006 (F).

CONSERVATION STATUS. With no confirmed records for over 95 years and no details about the plant's frequency or its habitat, this species can only be categorised as Data Deficient (DD) within IUCN guidelines. It is possible that it is extinct, but the author's experience of other old records from the Andes suggests this is unlikely to be the case and that this species may be refound after careful, focused search.

Stenostephanus sprucei (Lindau) Wassh. Ẽ J.R.I.Wood (Wasshausen \& Wood 2001: 449).

Cylindrosolenium sprucei Lindau (1897: 671). Type: Peru, R. Spruce 4371 (holotype $\mathrm{B} \dagger$, photo F, isotypes $\mathrm{BM}, \mathrm{BR}, \mathrm{G}, \mathrm{GH}, \mathrm{K}, \mathrm{MPU}, \mathrm{NY})$.

Herbaceous perennial. Inflorescence of pedunculate spikes 5 $-15 \mathrm{~cm}$ long, the flowers sessile in verticillasters along the rhachis; calyx lobes lanceolate-deltoid, finely acuminate, glabrous, $2-3 \mathrm{~mm}$ long, corolla pale lilac, glabrous, the tube slender, c. $6-7 \mathrm{~mm}$ long, lobes $2.5-3.5 \mathrm{~mm}$ long.

HABITAT \& DISTRIBUTION. Lowland rainforest in southern Ecuador and the northern half of Peru between 750 and $1200 \mathrm{~m}$. Map 1.

SPECIMENS EXAMINED. PERU. Amazonas: Condorcanqui, Cabeceras del Río Comainas, Puesto de Vigilancia "Alfonso Ugarte”, 355'S 78²5'24"W, 1000 - 1100 m, 19 July 1994, H. Beltrán Ė R. B. Foster 1038 (F, USM). Junín: [Chanhamayo], San Ramon, 750 m, 28 May 1979, D. C. Wasshausen E F F. Encarnación 1135 (K, US). San Martin: Tarapoto, R. Spruce 4371 (BM, NY); Zepelacio, near Moyobamba, 1100 - 1200 m, Oct. - Nov. 1933, G. Klug 3324 (K); Mariscal Cáceras, Campanilla, $7.4 \mathrm{~km} \mathrm{~N}$ of Pulcache, 743'S 7640'W, 900 - 950 m, 21 Dec. 1981, T. Plowman Eं J. Schunke-Vigo 11601 (K).

Stenostephanus wallnoeferi Wassh. (Wasshausen 2007: 184). Type: Peru, Huánuco, Prov. Pachitea, c. 24 km SE of Puerto Inca from "Campamento Sira", down valley of Río Negro, 9 ${ }^{\circ} 28^{\prime} \mathrm{S} 74^{\circ} 47^{\prime} \mathrm{W}, 650$ - 800 m, 16 March 1988, B. Wallnöfer E M. Henzel 110-16388 (holotype W, isotypes US, USM).

This species resembles Stenostephanus longistamineus in the form of its inflorescence, shape of its calyx lobes and distinct corolla shape - somewhat obovoid in bud. It differs in the larger, strongly 2-lipped corolla with the tube $35-38 \mathrm{~mm}$ in length, the upper lip 8 $10 \mathrm{~mm}$ long and the lower lip $16-18 \mathrm{~mm}$ long, 3lobed at the tip. The inflorescence branches, rhachis and pedicels are reddish-brown pubescent. The calyx is also reddish-brown but minutely glandular, rather than pubescent.

HABITAT \& DISTRIBUTION. Lowland rainforest, $650-800$ $\mathrm{m}$. Endemic to Peru and only known from the type locality. Map 5.

CONSERVATION STATUS. With a single collection and no details about the plant's frequency or of threats to its habitat, this species can only be categorised as Data Deficient (DD) within IUCN guidelines.

NOTE. Without seeing further specimens from the same area, it is difficult to be sure whether the distinctive differences with Stenostephanus longistamineus are maintained or if there are intermediates between the two species.

Stenostephanus wasshausenii J.R.I. Wood, sp. nov. Type: Peru, Puno, Carabaya, San Gaban, 900 m, 12 June 1982, D. C. Wasshausen E A. Salas 1251 (holotype US 2957095).

http:/ /www.ipni.org/urn:lsid:ipni.org:names:60479365-2

Subshrub, $1 \mathrm{~m}$ high; stem \pm quadranular, with abundant cystoliths but otherwise glabrous. Leaves subsessile (although possibly shortly petiolate below); lamina $6.5-27 \times$ $2-9.5$, slightly unequal in each pair, oblong-elliptic, acuminate, attenuate to a winged base, margin obscurely crenate, veins about 11 pairs, both surfaces glabrous, with abundant cystoliths, abaxially paler. Inflorescence an open, diffuse, repeatedly branched, glabrous panicle up to $20 \times 18 \mathrm{~cm}$, the flowers solitary or paired at the branch tips; bracteoles linear-lanceolate, $1-2 \mathrm{~mm}$ long, persistent; peduncles $3-7 \mathrm{~cm}$; secondary and subsequent peduncles $1-3 \mathrm{~cm}$, diminishing slightly in length towards the tips; calyx $12-20 \mathrm{~mm}$ long, glabrous, 5-lobed to near the base, the lobes 2.5 $3.5 \mathrm{~mm}$ wide, oblong, abruptly narrowed at apex to a broad green mucro; corolla c. $3.6-4 \mathrm{~cm}$ long, suburceolate and widened to c. $10 \mathrm{~mm}$ just above the middle, glabrous, reddish-purple, obscurely 2lipped, the limb composed of short, narrowly ovate, purplish lobes c. $3 \mathrm{~mm}$ long; stamens shortly exserted, filaments glabrous; anthers $6 \mathrm{~mm}$; style glabrous, stigma clavate. Capsule $17 \mathrm{~mm}$ long, glabrous, 4-seeded; seeds (immature), ovate in outline, $2 \times 1.5 \mathrm{~mm}$, reticulate. Fig. 8 .

RECOGNITION. Obviously related to Stenostephanus atrocalyx but distinguished by the much branched paniculate inflorescence, large calyx with lobes 12 $20 \times 2.5-3.5 \mathrm{~mm}$ and large glabrous corolla $3.6-$ $4 \mathrm{~cm}$ long.

HABITAT \& DISTRIBUTION. A rare species of rainforest in the Andean foothills from about 500 to $900 \mathrm{~m}$. It is known from only two collections and is endemic to Carabaya Province in the Puno region in the south of Peru. Map 1. 


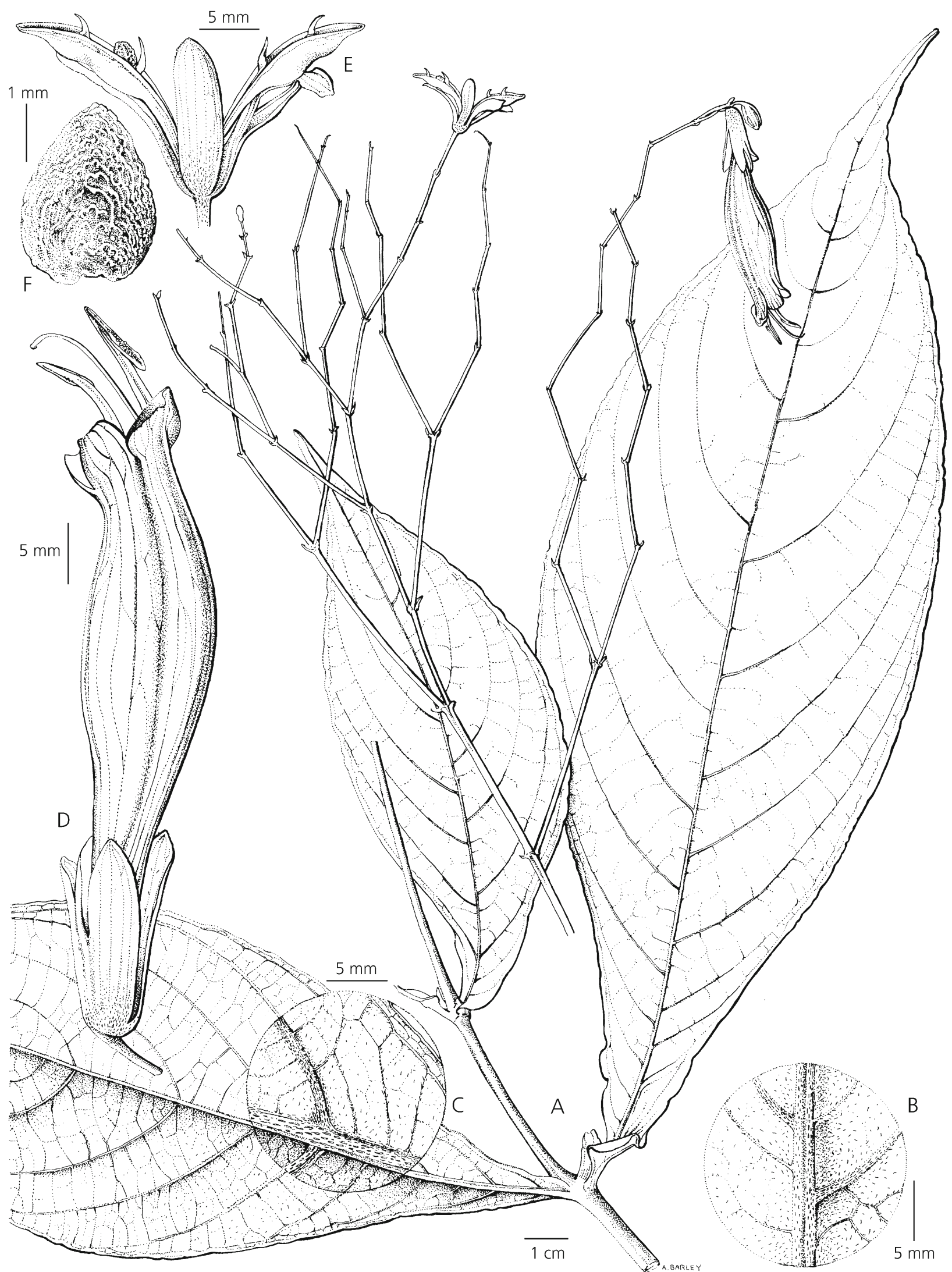

Fig. 8. Stenostephanus wasshausenii. A habit; B adaxial leaf surface; C abaxial leaf surface; D corolla and calyx; E capsule; F seed. From Wasshausen \& Salas 1251. DRAWN BY ANITA BARLEY. 
SPeCimens examined. Peru. Puno: Carabaya, Hac Palmera, 490 m, 4 March 1965, C. Vargas 16134 (US, ?CUZ); ibid., San Gaban, 900 m, 12 June 1982, D. C. Wasshausen Ẽ A. Salas 1251 (US).

CONSERVATION STATUS. With an area of occupancy of $8,000 \mathrm{~km}^{2}$, based on Geocat, this species should be provisionally classified as Critically Endangered (CR). It is only known from two collections, the most recent made almost forty years ago and at least one from an area of settlement that must be threatened by forest clearance. However, further studies will be needed to confirm this highly provisional classification.

EPONYMY. This species is named for Dieter Wasshausen, collector of the type specimen of this species and the leading expert on neotropical Acanthaceae since the 1970s. He has also been a generous friend, field companion and colleague of the author for more than 20 years.

\section{Stenostephanus sp. A = J. Schunke-Vigo 9844 \& 11339}

This is characterised by the narrow racemose thyrse c. $8 \mathrm{~cm}$ long and villous stems with dark red hairs. The corolla is white or cream, the calyx lobes filiform, 5 $6 \mathrm{~mm}$ long, glabrous or with a few glandular hairs. The leaves are reported to be dark red abaxially

SPECIMENS EXAMINED. PERU. Loreto: Coronel Portillo, Padre Abad, la cumbre de la Divisoria, 1500 - 1600 m, 6. Feb. 1978, J. Schunke-Vigo 9844 (US). Huánuco: Leoncio Prado, Hermilio Validizán, La Divisoria, carretera a Pucallpa, 1600 m, 21 April 1980, J. Schunke Vigo 11339 (US)

This might be an odd form of Stenostephanus davidsonii with a racemose inflorescence but is probably a distinct species. Material with fully developed corollas is needed before a decision can be made.

\section{Stenostephanus sp. B = L. Valenzuela et al. 3041}

L. Valenzuela et al. 3041 (FHO, MO) will key out next to Stenostephanus cuscoensis. The inflorescence is relatively short and lax but the rhachis, pedicels and calyx are densely villous. The corolla is only $1.9-2 \mathrm{~cm}$ long, reported to be creamy-yellow in colour and the stamens are included. As the latter is abnormal in Stenostephanus, this specimen may represent an atypical form. In any case more collections are needed to evaluate its status.

SPECIMEN EXAMINED. PERU. Cusco: La Convención, Santa Ana, Madre Selva, 1253'49"S 7245'02"W, 2300 - 3200 m, 20 March 2004, L. Valenzuela, E. Succli $\mathcal{F} G$. Calatayud 3041 (MO, OXF).

\section{Acknowledgements}

I am especially grateful to Anita Barley and Andrew Brown for drawing the plates that accompany this paper. I have also had valuable help from John Baker, Denis Filer and James Ritchie at Oxford in preparing this paper for publication. This would not have been possible without the loan of material from F, MO and US, which is gratefully acknowledged. Thanks are also due to staff at $\mathrm{K}, \mathrm{MO}$ and OXF, especially Jon Ricketson and Serena Marner, for help in processing loans and the use of their facilities.

Open Access This article is distributed under the terms of the Creative Commons Attribution 4.0 International License (http://creativecommons.org/ licenses/by/4.0/), which permits unrestricted use, distribution, and reproduction in any medium, provided you give appropriate credit to the original author(s) and the source, provide a link to the Creative Commons license, and indicate if changes were made.

\section{References}

Baum, V. M. (1982). New species and combinations in Odontonema (Acanthaceae). Brittonia 34: 424 - 434.

Champluvier, D. \& Darbyshire, I. (2009). A revision of the genera Brachystephanus and Oreacanthus (Acanthaceae) in tropical Africa. Syst. Ev Geogr. Pl. 79: 115 - 192.

Daniel, T. (2006). Synchronous flowering and monocarpy suggest plietesial life history for neotropical Stenostephanus chiapensis (Acanthaceae). Proc. Calif. Acad. Sci. 57: 1011 - 1018.

Hokche, O., Berry, P. E. \& Huber, O. (2008). Nuevo catálogo de la flora vascular de Venezuela. 1 - 859. Fundación Instituto Botánico de Venezuela, Caracas.

Lindau, G. (1897). Acanthaceae Americanae et Asiaticae novae vel minus cognitae. Bull. Herb. Boissier 5: 643 - 681 .

(1914). Acanthaceae. In: R. Pilger (ed.), Plantae Uleanae. Notizbl. Königl. Bot. Gart. Berlin 6: $192-200$. (1922). Neue Gattungen der Acanthaceen. Notizbl. Bot. Gart. Berlin-Dahlem 8: 142 - 144.

Nees von Esenbeck, C. G. (1847). Acanthaceae. In: A. P. de Candolle (ed.), Prodromus systematis naturalis regni vegetabilis 11: 46 - 519. Masson, Paris.

Ruiz, H. \& Pavon, J. A. (1798). Flora Peruviana et Chilensis Vol. 1: 1 - 78. Gabrielis de Sancha, Madrid. https://doi.org/10.5962/bhl.title.814.

Rusby, H. H. (1927). Descriptions of new genera and species of plants collected on the Mulford Biological Exploration of the Amazon Valley 1921 - 1922. Mem. New York Bot. Gard. 7: 205 - 387.

Wasshausen, D. C. (1985). New species of Hansteinia (Acanthaceae) from Colombia and Ecuador. Brittonia 37: 203 - 208. 
(1999a). The genus Stenostephanus (Acanthaceae) in Bolivia. Harvard Pap. Bot. 4: 279 - 288.

(1999b). In: P. M. Jørgensen \& S. León-Yánez (eds), Catalogue of the Vascular Plants of Ecuador. Monogr. Syst. Bot. Missouri Bot. Gard. 75: 1 - 1181.

(2007). A checklist of the Acanthaceae collected

in the "Sira Mountains" of Peru. Ann. Naturhist. Mus. Wien 108 B: 167 - 190.

(2013). Acanthaceae. In: C. Persson \& B. Stahl (eds), Flora of Ecuador, Vol. 179: 1 - 328. University of Gothenburg, Göteborg.

\& Wood, J. R. I. (2001). Further discoveries in the genus Stenostephanus (Acanthaceae) in Bolivia. Harvard Pap. Bot. 6: $449-454$.

\& _ (2004). The Acanthaceae of Bolivia.

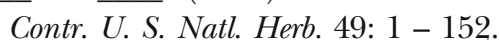

Wood, J. R. I. (1988). Colombian Acanthaceae some new discoveries and some reconsiderations. Kew Bull. 43: 1 - 51.

(2009). New names, combinations and synonyms in Justicia and Stenostephanus (Acanthaceae). Kew Bull. 64: 49 - 55.

(2016). Acanthaceae. In: R. Bernal, S. R. Gradstein \& M. Célis (eds), Catálogo de Plantas y Liquenes de Colombia 1: 583 - 611. Universidad Nacional de Colombia, Bogotá.

\section{Publisher's Note}

Springer Nature remains neutral with regard to jurisdictional claims in published maps and institutional affiliations. 